\title{
ИЗ ИСТОРИИ ПАМИРСКИХ ЯЗЫКОВ: БУДУЩЕЕ НАЧИНАЕТСЯ ВЧЕРА*
}

\begin{abstract}
В высокогорных долинах Памира Республики Таджикистан (РТ) проживают памирские таджики. Они сохранили древние восточноиранские языки и самобытную культуру. Сегодня носителей этих языков в Горно-Бадахшанской автономной области (ГБАО) Республики Таджикистан насчитывается свыше 150 тыс. человек. В статье дается анализ положения памирских языков в советское время, а также в период независимости Республики Таджикистан. Статья состоит из двух разделов, в которых показана история и особенности развития памирских языков (на примере шугнанского языка). Автор приходит к выводу, что несмотря на заметные успехи, достигнутые в этой сфере, предстоит еще многое сделать для сохранения памирских языков. Одной из первоочередных задач является фиксаџия наличия этих языков в ходе предстоящей переписи населения РТ в 2020 г.
\end{abstract}

Ключевые слова: Памир, Таджикистан, перепись, родной язык, памирские языки, шугнанский язык

«Памирские языки» это уже устоявшийся лингвистический термин. Еще в первые годы Советской власти один из пионеров памироведения И.И. Зарубин ${ }^{1}$ использовал данный термин (Бухерт 2011: 30; см. также: Зарубин 1924). Памирские языки распространены в Республики Таджикистан, в Исламской Республики Афганистан, в Пакистане и в Китае. К ним относятся бартангский, ваханский, ишкашимский, мунджанский, орошорский, рушанский, сарыкольский, старованджский, шугнанский и язгулемский языки. История систематического изучения памирских языков богата и связана с именами выдающихся ученых. Она берет начало во второй половине XIX в., когда К.Г. Залеман и Р. Шоу написали свои работы о шугнанском, ваханском и сарыкольском языках (Залеман 1895; Shaw 1876). Так как задачей настоящей статьи не является историография изучения памирских языков, мы отсылаем читателя к работам Д.И. Эдельман, Т.Н. Пахалиной, Д.К. Карамшоева, Л.Р. Додыхудоевой и Г. Моргиенстерна где есть историография и библиография данного вопроса (См.: Эдельман 1964: 128-138; Пахалина 1969; Карамшоев 1977: 126-133; Додьхудоева 1999: 170-174; Могgenstierne 1928; Morgenstierne 1938). Здесь же ограничиваемся показом распространения памирских языков на схематической карте иранских языков.

Каландаров Тохир Сафарбекович - кандидат исторических наук, старший научный сотрудник Института этнологии и антропологии РАН (Москва, Ленинский пр., 32a). Эл. почта: tohir_ s70@mail.ru. Kalandarov Tohir S. - Institute of Ethnology and Anthropology, RAS (Moscow, Leninskiy prospect, 32a).E-mail: tohir_s70@mail.ru

* Публикуется в соответствии с планом научно-исследовательских работ Института этнологии и антропологии РАН

${ }^{1}$ Большой лингвистический и этнографический материал по народам Памира содержится в архиве И.И. Зарубина, который находится в Институте восточных рукописей в Санкт-Петербурге. 


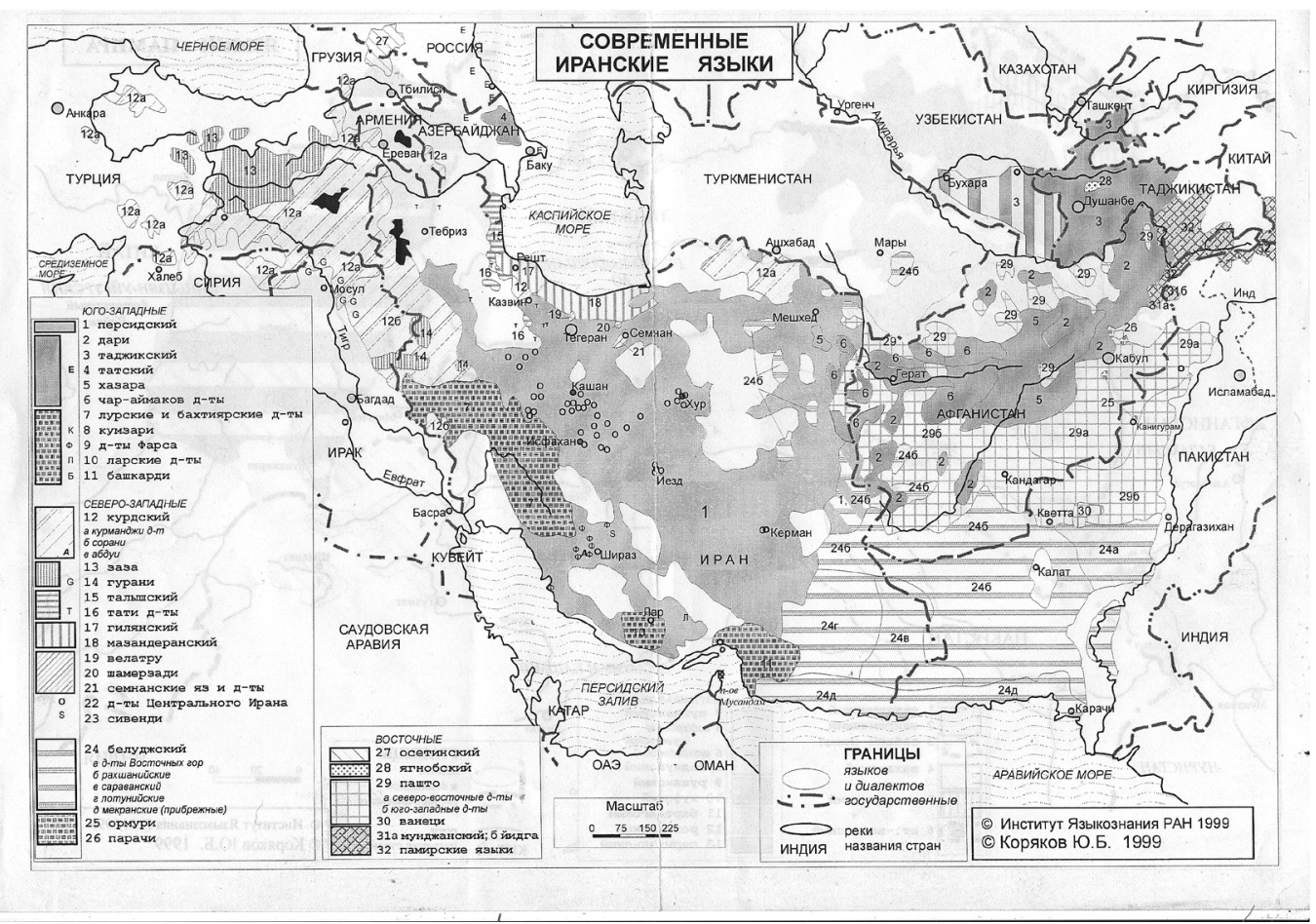

Рис. 1. Распространение иранских языков (Языки мира 2000).

Статья написана на основе анализа редких книг на шугнанском языке, опубликованных в 1930-е гг. и современной литературы по теме малых и бесписьменных языков, а также на данных собственных полевых исследований (ПМА), проводившихся в сентябре 2016 и августе 2019 гг. Полевой материал был в основном собран в городе Хорог, в Шугнанском и Рошткалинском районах ГБАО. Методика полевой работы заключалась во включенном наблюдении (шугнанский язык является родным языком автора) и записи интервью с ключевыми информантами - активистами неправительственных организаций (НПО), поэтами, которые пишут стихи на памирских языках, и с обычными носителями этих языков. Кроме того, при подготовке данной статьи активно использовался и другой метод работы - мониторинг социальных сетей (Facebook, Одноклассники) с целью поиска стихотворений на памирских языках авторов аккаунтов.

Теоретическая база исследования основана на рассуждении Э. Хобсбаума, согласно которому «чтобы вывести язык из дома и с улицы в широкий мир, ему больше не нужно давать официальный статус» (Hobsbawm 1997: 90). На основе анализа современного интернетного распространения памирских языков мы попытаемся обосновать эту мысль Э. Хобсбаума. В данной статье речь в основном идет о шугнанском языке на территории современного Таджикистана - самом распространённом среди памирских таджиков языке. По мнению Ш.П. Юсуфбекова, шугнанский язык в настоящее время наряду с таджикским становится вторым «региональным» языком на Памире (Юсуфбеков 2011: 279).

Первое упоминание о шугнанском языке мы находим в записках китайского путешественника и монаха Сюана Цзана, который во второй четверти VII в. проходил через Ваханскую долину в Китай. Вот что он пишет: «Письменность (шугнанская - 
Т.К.) такова же, как в стране Духоло (т.е. Тохаристан - Т.К.), а язык имеет отличия» (Сюань-изан 2012: 326). В 20-х годах VIII в. другой китайский паломник Хой Чао, проезжая через Вахан, на основе расспросов описал язык шугнанцев как «особый, отличный от языков жителей других владений» (Цит. по: Мандельштам 1957: 123).

К сожалению, о шугнанском языке, как и впрочем, о других памирских языках, в древности и средневековье мы имеем очень скудный материал. Если о Шугнане и шугнанцах еще можно найти упоминания, то об их языке у нас практически нет информации. Как говорилось выше, только в XIX в. началось научное изучение памирских языков. Подсчет их носителей был впервые произведен в 1926 г. В переписных листах 1926 г. - первой Всесоюзной переписи населения, в которых упоминались памирские народы, - существовала графа «народность» и «родной язык». Во время этой переписи своим родным языком указали ваханский язык 6 человек, шугнанский язык - 6 человек, рушанский язык - 9 человек, язгулямский язык - 1019 человек (Народность 1928: 24, 26). Как видно по этим данным, из всех памирских народов только язгулямцы (практически все) назвали язгулямский язык в качестве родного. По словам того же И.И. Зарубина, в 1925 г. в Язгуляме насчитывалось примерно 200 домов (Зарубин 1925: 5).

Понятие «родной язык» до сих пор вызывает бурные дискуссии среди ученых и чиновников. Как известно, в 2020 г. в Республике Таджикистан, также как и в России планируется перепись населения. Некоторые ученые являются сторонниками двойного обозначения своего родного языка во время переписи. По их мнению, у человека может быть больше одного родного языка. Хотя следует отметить, что не все соглашаются с такой точкой зрения. Вот что об этом пишет лингвист Х.Д. Шамбезода: «Нами в корне отрицается возможность существования более одного родного языка, так как, во-первых, это недостаточно оправдано, во-вторых, возможность существования второго “родного" языка обычно влечет за собой вывод о безболезненности замены этнического языка, что мы частично имеем в ситуации с памирскими языками» (Шамбезода 2007: 344). Если родной язык считать материнским языком, то, по словам В.Г. Костомарова, у человека не может быть двух материнских языков (Костомаров 1991:11). Однако, на наш взгляд, в ситуации, когда дети рождаются в смешанных браках, у них может быть два родных языка. Именно такого мнения придерживается Ю.В. Рождественский. Он считает, что «у детей в семьях со смешанным по национальному происхождению составом может быть два и более родных языка» (Рождественский 2002: 40).

Приведем также и позицию академика В.А. Тишкова: «Признание права на родное двуязычие снимет напряжение и чувство неловкости, которое испытывают многие россияне, когда им приходится выбирать между родными для них языками отца и матери или просто между двумя в равной мере родными для них языками» (Тuшков 2016: 302).

Летом 2015 г. председатель Комитета по языку и терминологии при Правительстве Республики Таджикистан сообщил на пресс-конференции о том, что в связи с угрозой исчезновения памирских языков создается рабочая группа по их изучению (Хуршеди, Шахлои 2015). Складывается парадоксальная ситуация: во время переписи 2010 г. никто не заявил о себе как носителе данных языков, но правительство республики думает об их спасении! Важно напомнить, что, по данным Всесоюзной переписи 1989 г., свыше 101 тыс. человек в качестве родного языка называли один 
из памирских языков (см.: Моногарова 2001: 47). Отметим также, что в Законе о государственном языке Республики Таджикистан от 5 октября 2009 г. № 553 в статье 4 сказано: «Республика Таджикистан создает условия для свободного применения, защиты и развития бадахшанских (памирских) языков и ягнобского языка» (Закон 2009: 4). Как справедливо отмечает В.А. Тишков: «Языковые вопросы традиционно присутствуют в переписях многих государств, ибо на основе этих данных определяется язык (или языки) бюрократии, на котором она должна общаться с налогоплательщиками, разрабатывается информационно-образовательная политика, а также меры по поддержке тех или иных языков, если в этом есть необходимость» (Тишков 2007: 50). Конечно, граждане обязаны знать государственный язык, но, к примеру, если в каком-то кишлаке полицейский заходит в дом, а там только пятилетний ребенок, родной язык которого отличается от государственного, то, скорее всего, полицейский обязан говорить с ним на языке, понятном ребенку.

Язык сам по себе является достоянием любого государства, тем более такие древние, но бесписьменные языки, как памирские, вдвойне нуждаются в опеке со стороны властей страны. Надо отметить, что в 30-е годы XX в. памирская интеллигенция (и не только она) ${ }^{1}$ пыталась создать алфавит для местных языков. Особое место в продвижение в деле составления алфавитов для памирских языков сыграл первый научный Съезд таджикских лингвистов, который проходил 22 августа 1930 г. в Сталинабаде. Один из пунктов регламента Съезда был посвящен шугнанскому алфавиту. По данному вопросу выступил А. Дьяков (Охонниёзов 2012: 44).

Тогда в первую очередь начали создавать алфавит для шугнанского языка - наиболее распространённого на территории Памира, на котором сегодня говорит примерно 90 тыс. человек. В эту трудную FUKAЪ RANĢBARENI DINJO JI SET

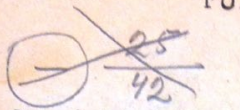

Novişiçen: Şamizizodāt, Musrifşojifat, ii) $\ \frac{1}{23}$ Bandişojiff.

\section{XUGNONI}
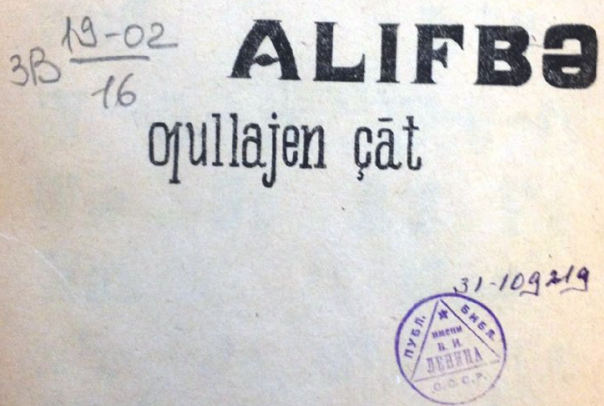

Naşrijoti davlatijji Sita linobod-1931-Toşkand

Рис. 2. Букварь для взрослых (из личного архива автора). и, как оказалось впоследствии, опасную работу включился и молодой поэт Нодир Шамбезода ${ }^{2}$ - шугнанец по происхождению. Шугнанский алфавит был создан на основе латинской графики. Один из первых учебников был выпущен в 1931 г., и

\footnotetext{
${ }^{1}$ Например, в создании шугнанского алфавита участвовали шведский иранист Х. Шельд и русский врач и историк А. М. Дьяков. Примечательна статья Дьякова о сложностях книгоиздания на памирских языках (Дьяков 1931: 85-90).

2 Шамбезода Нодир (1908-1991) - поэт, основоположник литературы на шугнанском языке (см. подр. о нем: Охонниёзов 2012; Абдулназаров 2012: 9-13).
} 
примечательно, что он в первую очередь предназначался для взрослых, так как в то время проходила кампания по ликвидации массовой безграмотности (ликбез). Авторами учебника были Н. Шамбезода, Х. Мусрифшоев и Б. Бандишоев (Букварь 1931).

В данной статье впервые представлены некоторые отсканированные страницы книг на шугнанском языке. Введение этого редкого библиографического материала в научный оборот является актуальным и значимым для дальнейшего изучения этнокультурных процессов на Памире и в прилегающих странах. Практически все эти книги иллюстрированы чёрно-белыми рисунками. Отражением атмосферы и событий того времени стала публикация в этих учебниках многочисленных политических лозунгов и стихов, прославляющих пролетарские массы и Красную Армию. В качестве примера приведем стихотворение о красных солдатах.

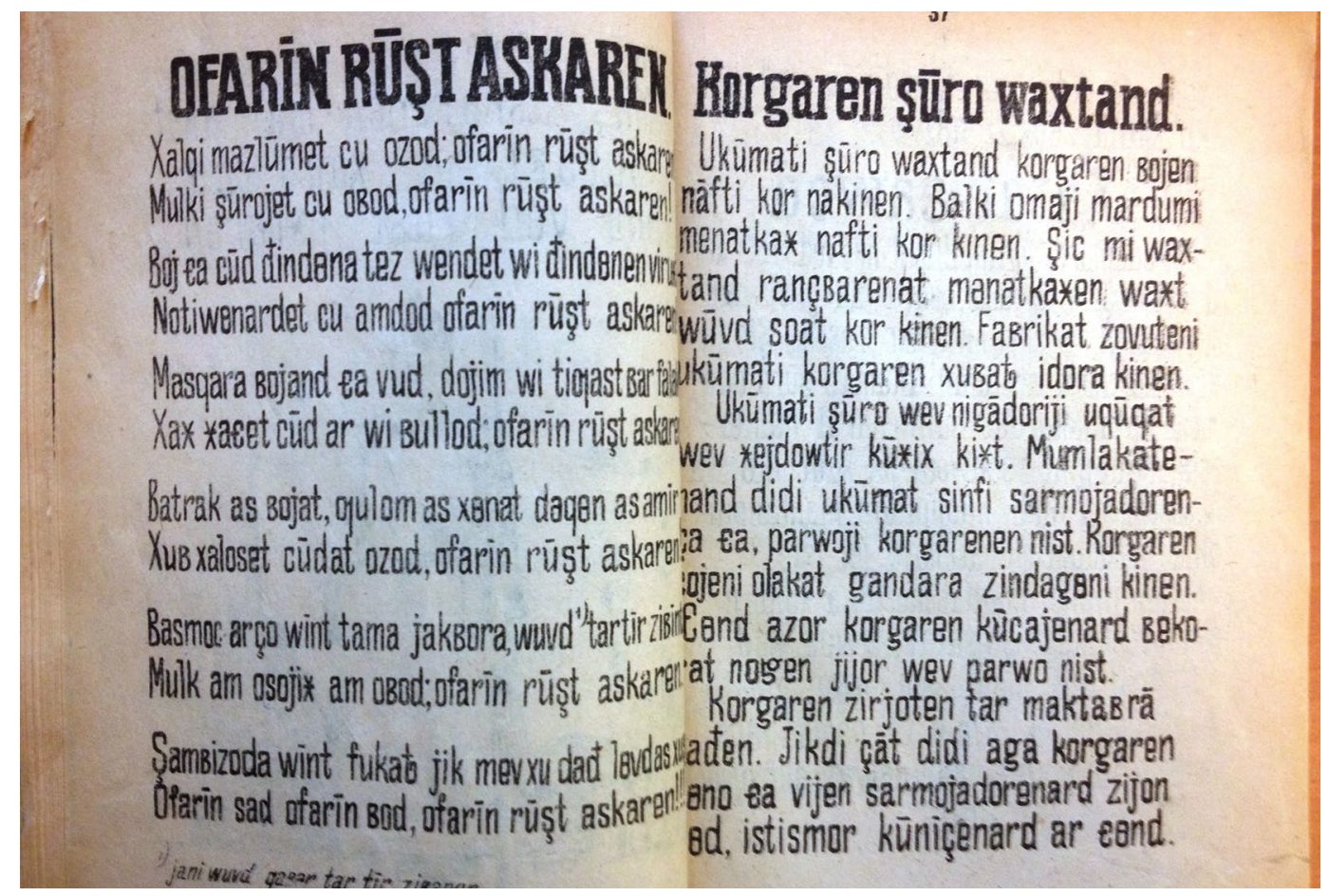

Рис. 3. Стихотворение Н. Шамбезаде о Красной Армии (из личного архива автора).

Смысловой перевод с шугнанского на русский язык ${ }^{1}$ :

Вы освободили угнетенный народ, хвала вам, красные солдаты,

Страну Советов благоустроили, хвала вам, красные солдаты,

Богачи, которые показали зубы, вы сломали им зубы,

Беднякам вы помогали, хвала вам, красные солдаты,

Насмешка богачей, которые всегда смотрели с высока,

Вы затопили их фундамент, хвала вам, красные солдаты,

Бедняка от богача, раба от хозяина и дехканина от эмира,

Вы отважно освободили, хвала вам, красные солдаты,

Басмач, когда видит вас, прячется в могилу,

Страна спокойная и цвветущуая, хвала вам, красные солдаты,

\footnotetext{
${ }^{1}$ Все смысловые переводы с шугнанского языка на русский выполнены автором статьи, кроме тех, авторство которых специально обозначено.
} 
Увидев все это, Шамбезода кричит от радости,

Хвала, стократная хвала, хвала вам, красные солдать (Букварь 1931: 36).

Как видим, в стихотворении воспевается новый Советский строй на Памире. В другом произведении из этого учебника поэт Шамбезода восхваляет новую школу, противопоставляя её прежней. В нем говорится о том, что старая школа не могла дать ученикам знания, а в новых школах ученики умеют не только писать и читать, но и могут рассказать о международных делах. Таким образом, автор отмечает политическую грамотность учащихся советской школы (Там же: 39-40). Далее на стр. 42 написано о том, что во время болезни нужно идти не к муллам, а к врачам, т.к., по мнению авторов, муллы используют неграмотность людей ради своего обогащения. Резюмируя медицинскую тему, авторы пишут, что против разных болезней врачи и мудрецы готовят лекарства, которые надо пить, чтобы поправить здоровье, иначе любая болезнь может привести к печальному исходу. В учебнике также написано о полезности чтения газет, в которых есть социально-экономические и политические новости (Там же: 42-43). Так как учебник был рассчитан на взрослых, в него включен отдельный небольшой текст о вреде опиума ${ }^{1}$. Особое внимание уделено социальным последствиям курения опиума, например, сказано, что курильщик опиума может лишиться своей земли, сада и будет вынужден заниматься воровством. Авторы призывают каждого члена общества бороться против курения опиума и в конце этого текста в стихотворной форме высмеивают курильщиков (Там же: 51-53).

В учебнике также рассказывается о преимуществах колхозов, коммун и артелей, о том, что дехкане должны сообща покупать технику (Там же: 56-59). Несомненный интерес представляет раздел, посвященный развитию шелководства на Памире. Слова об экономическом эффекте этой отрасли сельского хозяйства авторы подкрепляют конкретными цифрами - за два пуда (примерно, 32 кг) государство платит дехканам 130 рублей (Там же: 60-62). Специальный раздел посвящен также хлопководству (Там же: 63-65). Конечно, особое внимание уделяется ликвидации безграмотности среди населения. Для подчеркивания важности этих мер в книге приведены слова основателя Советской власти В.И. Ленина о том, что «безграмотный человек вне политики» (Там же: 72-73). Далее дается краткая информация о комсомоле, профсоюзе и пионерской организации (Там же: 84-94), характеристика герба СССР и основ Советского государства (Там же: 95-104). Авторы особо отмечают равноправие мужчин и женщин в Стране Советов, рассказывают о высшем органе Советской власти - Съезде Союза Советских Социалистических республик (Там же: 108-112) и указывают, какие категории людей в Советском Памире не имеют право голоса - они перечислены порядковыми номерами. На первом месте указаны те, кто ради своей выгоды используют труд других людей, на втором месте - владельцы заводов и фабрик, которые также используют чужой труд. Хотя на Памире в 1930-е гг. еще не было крупных заводов и фабрик, тем не менее, авторы эту общую тенденцию экономического развития Со-

${ }^{1}$ Надо отметить, что курение опиума было распространённым занятием среди памирских народов и только с присоединением края к царской России в 1895 г. началась систематическая борьба против этой болезни. К примеру, один из первых правителей царской администрации на Памире Кивикэс издал специальный указ о борьбе с опиумокурением на Памире (Подробнее о Кивикэсе см.: Худоназаров 2008: 76-80). Красочный рассказ про отца-курильщика опиума приведен в шугнанских текстах И.И. Зарубина (Зарубин 1960: 15-16). 
ветского государства спроецировали и на Памир. В третью категорию были включены торговцы, лавочники и посредники в торговых делах. В четвертую - ишаны и халифы, которые занимаются религиозными делами, в пятую - служащие старой царской администрации, в шестую - психически нездоровые люди, и в седьмую люди, имевшие судимость. Отдельно в учебнике освещается советские праздники, такие как 1 мая, 8 марта (Там же: 129-134). Небольшой очерк в учебнике посвящен основателю Советского государства В.И. Ленину (Там же: 136-141). Хотя учебник был написан для взрослых, тем не менее, в нем много иллюстраций и он был выпущен большим тиражом - 3000 экз.

Особо стоит рассказать об авторах этого учебника. Если Шамбезода - достаточно известная личность в Таджикистане и даже за его пределами, то о двух других авторах имеется очень мало информации: лишь небольшие очерки в книге Ш. Шонаврузова и М. Хайдаршо «Три поколения учителей Бадахшана». Второй автор данного учебника Хусрав Мусрифшоев родился в 1908 г. в долине Поршинев. В 1925 г. он поступил в Ташкенте в Институт подготовки учителей, но не успел закончить его и по вызову областного отдела коммунистической партии приехал в Хорог. Там он начал

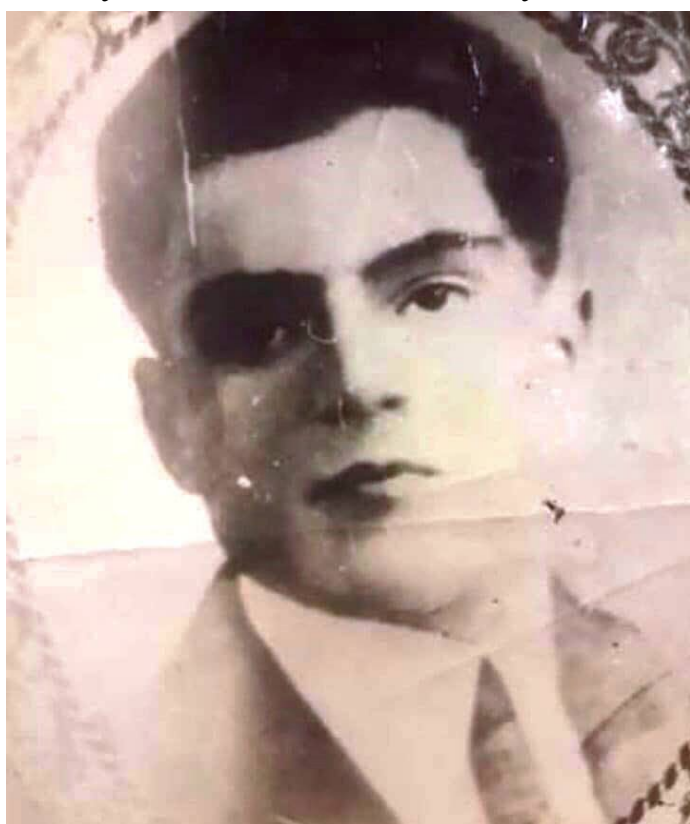

Рис. 4. Хусрав Мусрифшоев (из личного архива Х. Давлатова).

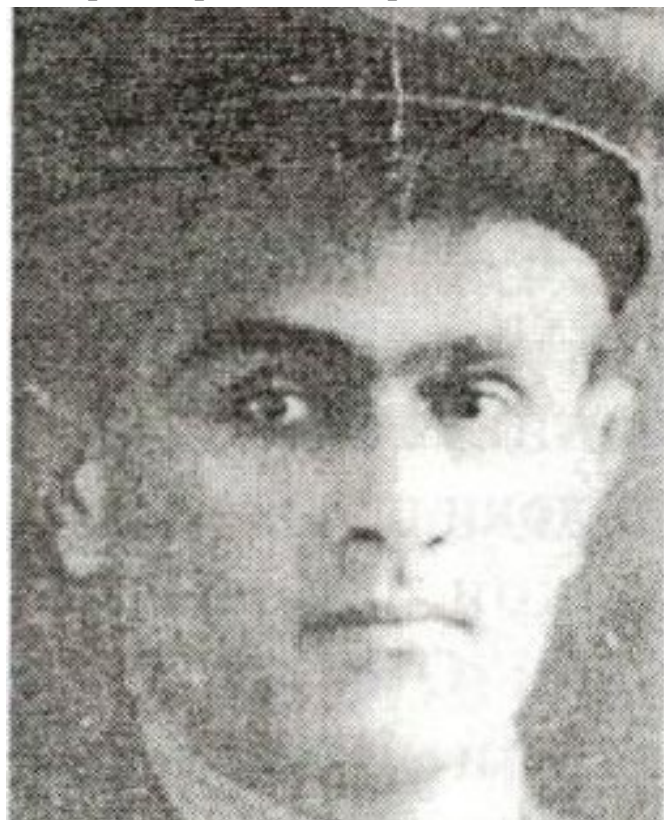

Рис. 5. Богшо Бандитоев (из книги Шугнан 2017).

работать учителем в школе, позднее его назначили руководителем курсов повышения квалификации учителей области. При этом он не оставлял свою педагогическую деятельность. Молодых учителей области на своих открытых уроках в школе он обучал основам и методике педагогической работы. В 1929 г. Мусрифшоев второй раз поехал в Ташкент и поступил на юридический факультет Среднеазиатского коммунистического университета. В 1932 г. после окончания университета возвратился обратно в свой родной край. С 1932 по 1935 гг. работал прокурором Шугнанского района. В 1935 г. его назначили заведующим отделом образования ГБАО. К сожалению, в 1937 г. по ложным обвинениям он был объявлен врагом народа и репрессирован 
(Шонаврузов, Хайдаршо 1991: 20-23). С 1967 г. одна из средних общеобразовательных школ Поршинева носит имя Хусрава Мусрифшоева ${ }^{1}$.

Третий автор учебника Бандишоев Богшо тоже родился в 1908 г. в долине Поршинев. В 1923 г. он поступил в старшие классы школы-интерната города Хорога. После года обучения его как способного ученика отправили в Ташкент в Институт подготовки учителей. После двух лет учебы юноша возвратился в родной Хорог. Сначала Бандишоев работал учителем, но вскоре, приняв во внимание его личные лидерские качества, был назначен секретарем комсомольской организации только что образованной области ${ }^{2}$. На комсомольской работе он проявил себя как способный и перспективный кадр, и в 1929 г. поступил в Среднеазиатский коммунистический университет, который успешно закончил в 1931 г. После окончания учебы его зачислили в аспирантуру, по завершению которой Богшо возвратился на Памир и был назначен первым заместителем председателя облисполкома. В 1936 г. лично Шириншо Шотемур ${ }^{3}$ пригласил его в Душанбе и предложил должность заведующего Орготделом Центрального Исполнительного Комитета Республики Таджикистан. Однако сталинская репрессивная машина не пощадила ни Шириншо Шотемура, ни Богшо Бандишоева, жизнь которого оборвалась в 1937 г. (Шонаврузов, Хайдаршо 1991: 33-34).

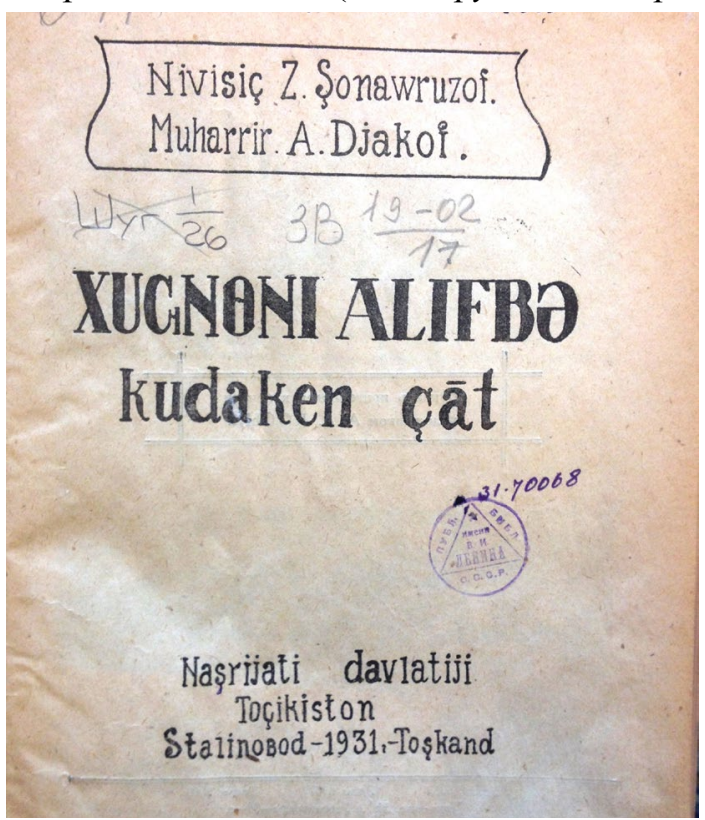

Рис. 6. Букварь

(из личного архива автора).

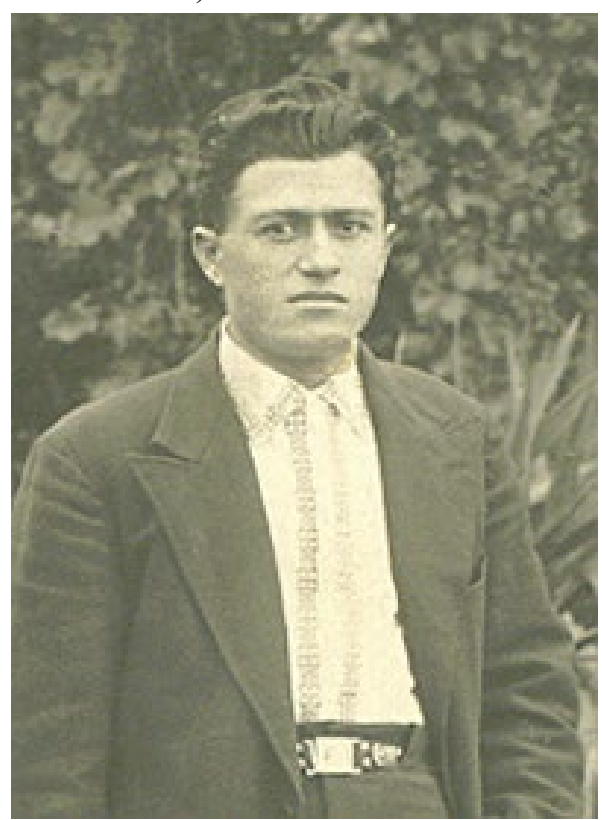

Рис. 7. Зоолшо Шонаврузов (из личного архива Шонавруза Афзалшоева).

Также в 1931 г. был выпущен букварь 3. Шонаврузова на шугнанском языке (Шонаврузов 1931). Автор этого учебника Зоолшо Шонаврузов родился в 1912 г. в Хороге.

\footnotetext{
${ }^{1}$ Выражаю благодарность Хушкадаму Давлатову и Шонаврузу Афзалшоеву за предоставленную информацию о Хусраве Мусрифшоеве.

${ }^{2}$ ГБАО была образована 2 января 1925 г.

${ }^{3}$ Шириншо Шотемур (1899-1937) - советский политический, партийный и государственный деятель. Репрессирован в 1937 г. Похоронен в братской могиле в Москве. Указом Президента РТ от 27 июня 2006 г. ему присвоено высшее звание в стране - Героя Таджикистана.
} 
Зоолшо Шонаврузова по праву считают первым пионервожатым на Памире. Когда в 1926 г. в Хороге был организован первый пионерский отряд ГБАО, Зоолшо был «сыном полка» при Хорогском пограничном посте и уже довольно хорошо владел русским языком. На первом же собрании отряда пионеров его избрали вожатым. В его пользу было и рекомендательное письмо от начальника особого отдела хорогского погранотряда А.Я. Дуккура. В 1927 г. молодого Зоолшо отправили учиться в партийную школу в Душанбе, а уже через год он поступил в Среднеазиатский коммунистический университет. После окончания учебы он опять возвратился на Памир и до конца жизни (1966 г.) работал на ответственных постах в партийных и советских органах (Шонаврузов, Хайдаршо 1991: 35-37). В 1930-ые годы 3. Шонаврузов в местной газете «Бадахшони сурх» (Красный Бадахшан) - печатном органе областной коммунистической организации, публиковал свои стихи на таджикском языке. Одно из его них, посвященное весне, было размещено в двенадцатом номере этой газеты (Шонаврузов 1936).

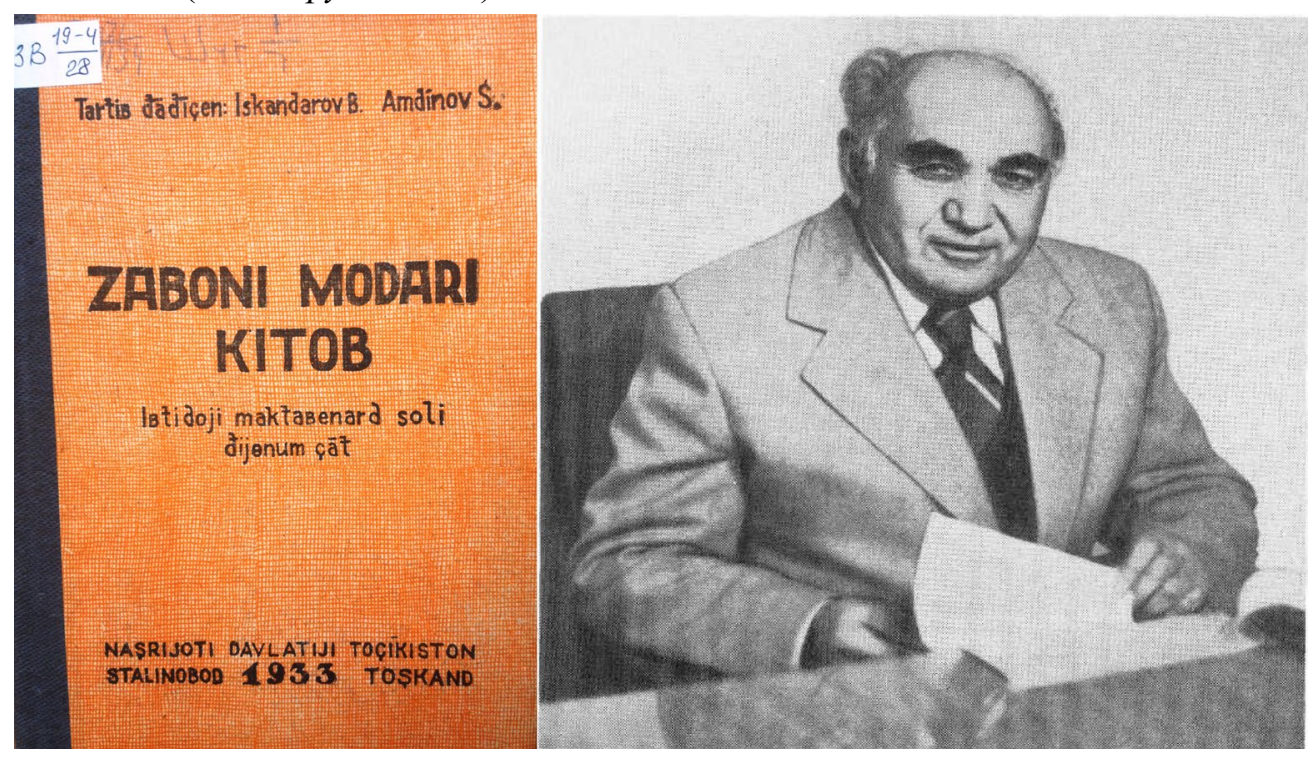

Рис. 8. Учебник (из личного архива автора) и один из авторов, будущий академик Б.И. Искандаров (из Википедии).

В 1933 г. Б. Искандаров ${ }^{1}$ и С. Амдинов издали «Учебник родного языка для второго класса» (Искандаров, Амдинов 1933). Если Б.И. Искандаров позже стал известной личностью в Таджикистане и за ее пределами, то об Сафармамаде Амдинове известно очень мало. В Энциклопедии Бадахшана о нем есть небольшая статья, в которой указано, что С. Амдинов родился в 1911 г. в Хороге. После окончания школы-интерната в Хороге поступил в Ташкентский институт подготовки учителей, где обучался с 1927 по 1929 г. Свою трудовую деятельность он начал с должности директора курсов подготовки учителей в Шахристонском районе Ленинабадской области (ныне Согдийская обл.). Некоторое время, с 1937 по 1940 г., он жил и работал

${ }^{1}$ Искандаров Б.И. (1912-2004) - академик Академии наук Республики Таджикистан. В 2012 г. по решению Правительство Республики Таджикистан Институту гуманитарных наук Академии наук Таджикистана было присвоено имя академика Баходура Искандаровича Искандарова. (Подробнее о нем см.: Баходур Искандаров 2013) 
в г. Ош Киргизской ССР. После возвращения в Таджикистан работал на разные должностях: директором средней школы, методистом Института усовершенствования учителей ГБАО, заведующим отделом гороно Хорога. С 1964 по 1990 гг. был председателем профсоюзного комитета высших учебных заведений Таджикской ССР. Умер С. Амдинов в 1997 г. (Энциклопедия Бадахшана: 37). Амдинов как и Шонаврузов в молодости писал стихи на таджикском языке и в том же двенадцатом номере газеты «Бадахшони сурх» опубликовал одно свое стихотворение, посвященное крестьянам (Амдинов 1936).

В 1937 г. Шамбезода выпустил букварь шугнанского языка для первого года обучения (Шамбезода 1937).

Как полагается, в букваре дается правописание всех букв шугнанского языка, каждая буква имеет отдельную иллюстрацию. Несмотря на то, что

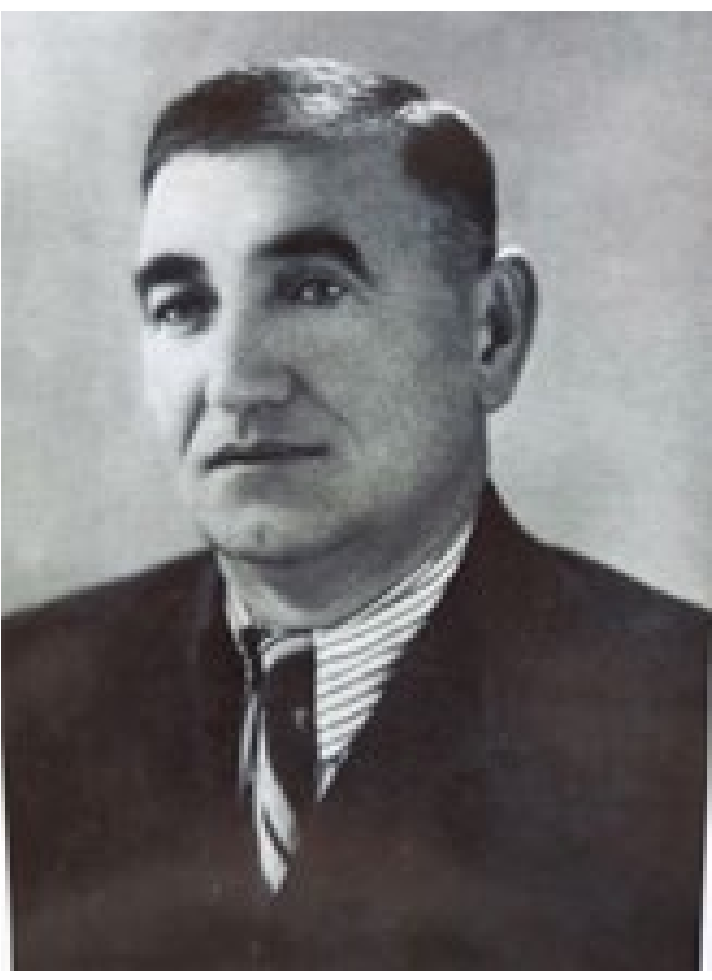

Рис. 9. Амдинов Сафармамад (из личного архива Сафармамдовой Асиятмо). книга написана для первоклассников, в ней есть много политических лозунгов, типичных для первых лет Советской власти. Например, на стр. 44 говорится о равноправии и свободе женщин.
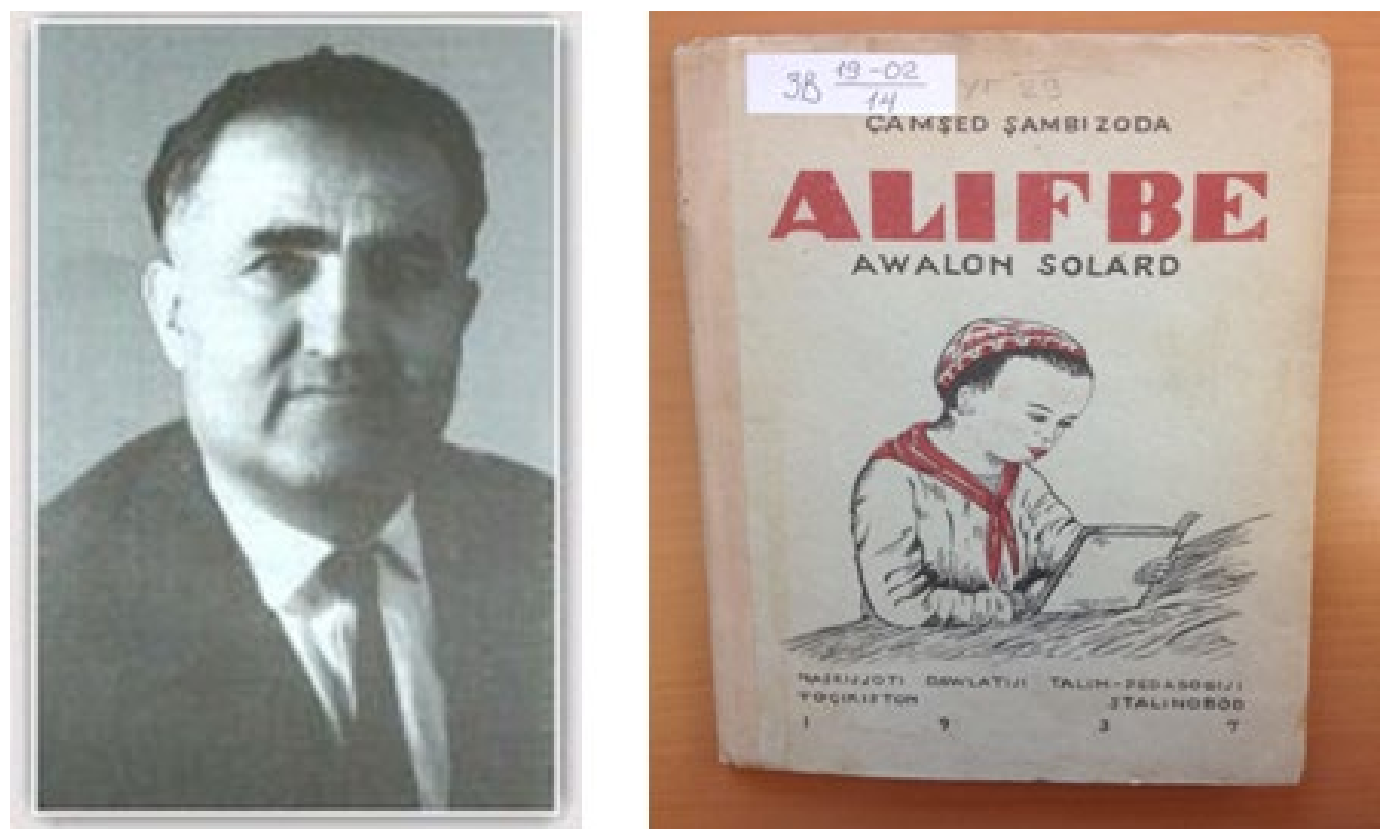

Рис. 10. Н. Шамбезода и его букварь (из личного архива автора). 


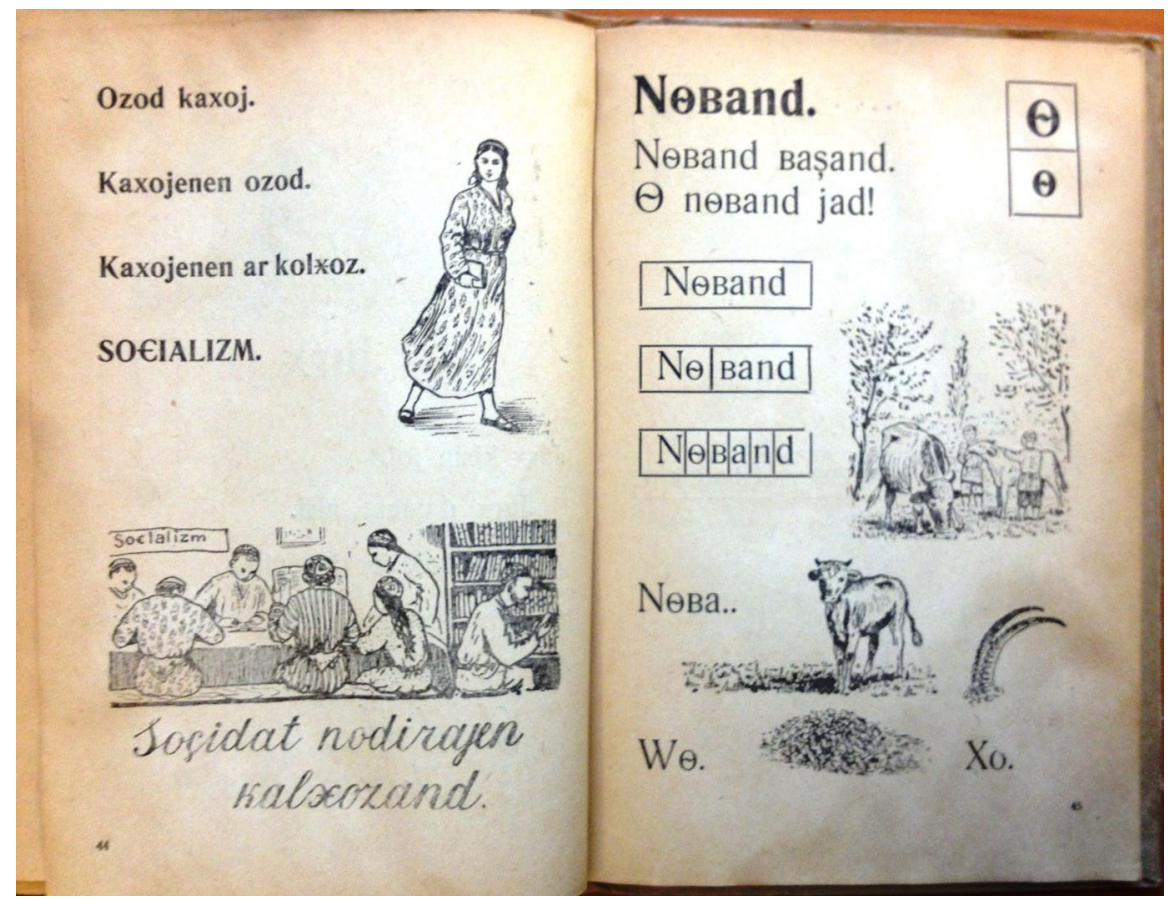

Рис. 11. Свободная женщина (из личного архива автора).

Помимо этого, в 30-е годы XX века на шугнанский язык были переведены несколько книг для чтения (Фортунатова 1937; Карим 1938). Однако тогда этот алфавит не нашел применения, поскольку власти обвинили его авторов в национализме. Но, несмотря на это, до конца 1937 г. было сделано очень многое в деле языкового строительства. Как справедливо отмечают В.М. Солнцев и В.Ю. Михальченко: «Советский опыт языкового строительства в первые десятилетия Советской власти уникален. Он не имеет аналогов в языковой истории человечества... Была создана письменность для 50 ранее бесписьменных языков, на них стала издаваться литература, было организовано обучение» (Солнщев, Михальченко 1990: 15). До 1937 г. на Памире, как пишут лингвисты А.Л. Грюнберг и И.М. Стеблин-Каменский, в школах использовалась нововведенная шугнанская письменность, однако в этом печально известном году она была отменена и ликвидирована. «Эта акция, - подчеркивают исследователи, - была частью проводившейся при Сталине под флагом борьбы с местным национализмом... политики по искоренению национального своеобразия и разнообразия... В ходе этой кампании... деятели, ратовавшие за развитие письменности и культуры на родном языке, репрессированы» (Грюнберг, Стеблин-Каменский 1989: 37). Именно в 1937-1938 гг. Сталин начал вести беспощадную войну с приверженцами широкого распространения и внедрения национальных языков; начался период так называемой антикоренизации (см.: Губогло, Сафин 2000: 282-287; Fouse 2000: 312-313). Один из авторов алфавита Н. Шамбезода чудом не подвергся физической расправе, хотя тюремного срока ему избежать не удалось. В 1937 г. поэт опубликовал книгу своих стихов на шугнанском языке под названием «Гулzунча» (Бутон) (об этой книге см.: Охонниёзов 1998: 5-18; Он же 2012: 68-96). Предисловие к этой книге написал известный лингвист-иранист С.И. Климчицкий (1899-1941). В своем предисловии он пишет о том, что «...поэт Шугнана Шамбезода...был вы- 
нужден в своем творчестве использовать новые шугнанские формы и метры. Этот сборник один из первых успехов в этой сфере» (Цит. по Охонниёзов 2012: 75). Данный сборник стихов стал одной из причин давления на автора. Как часто бывало в те годы, посыпались анонимки в разные органы государственной власти. Так, на имя секретаря партийного комитета Шугнанского района некие «благодетели» в своем письме вынесли следующий вердикт: «В заключение, книга “Гулгунча” без всяких сомнений является антиреволюционным трудом и не связана с реализмом. Поэтому надо скорее запретить продажу этой книги. Вопрос об оставлении или отчислении автора от рядов партии, в рядах которой он состоит, пусть решает партийная организация» (Там же: 77). Как видим, очень сурово и в духе времени. В 1937 г. автору «Гулгунча» не мог помочь первый секретарь коммунистической партии большевиков Таджикистана С.К. Шадунц ${ }^{1}$, который 11 ноября 1937 г. был арестован. До своего ареста, судя по статье самого Шамбезода, которую он опубликовал в газете «Точчикистони сурх» (Красный Таджикистан) С.К. Шадунц был сторонником использования шугнанского алфавита (Охонниёзов 1998: 15-16).

«Уже в 1939 г. в решении VI Пленума Горно-Бадахшанского обкома КП (б) Таджикистана (7-8 января 1939 г.) говорилось о том, что “тенденция к изданию учебников и преподаванию на шугнанском языке является вредной и становится тормозом для развития и процветания культуры таджиков Горного Бадахшана» (Аламшоев 2009: 180).

Возможно, поэтому в биографическом указателе советских писателей Таджикистана не нашлось места для Н. Шамбезоды (см.: Советские писатели 1949).

Сам же Н. Шамбезода, несмотря на то, что был автором нескольких сборников стихов на таджикском языке, считал себя в первую очередь шугнаноязычным поэтом. Вот как об этом он сказал в одном из своих интервью: «Я начал писать стихи на шугнанском языке, а потом перешел на таджикский, но при этом не перестал сочинять на родном языке. На таджикском языке вышли многие мои стихи, и я известен среди любителей поэзии, на шугнанском же языке ничего не вышло, хотя я стремился к этому почти с 30-го года. Вскоре я убедился, что настоящий поэт я именно на родном шугнанском языке, ибо ту философию жизни, то мастерство, которые были в моей шугнанской поэзии, я очень редко замечал в своих таджикских сборниках. А это потому, что каждый человек (в этом и я убедился) никогда не сможет на чужом ему языке (как бы прекрасно он его ни знал) красиво и выразительно высказать свою мысль так, как он это сможет сделать на родном языке» (Шорахматуллоев 1990).

В этой же статье автор публикации - известный поэт А. Шорахматуллоев ${ }^{2}$, критикует интеллигенцию ГБАО за то, что она способна больше говорить, чем делать: «До каких пор это может продолжаться! Ведь у читателей уже сложилось такое впечатление, что эти каждодневные статьи пишутся не в пользу языков, не из-за любви к ним, а просто из-за гонорара... Надо же от слов когда-то перейти к делу» (Там же). Иногда сам факт наличия памирских языков ставится под сомнение, и их преднамеренно считают диалектами. Такого рода суждения исходят не только от чиновников разного рода, а порою и из уст творческой интеллигенции. Примером может послужить обращение молодых таджикских литераторов к парламенту Таджикской ССР, кото-

${ }^{1}$ С.К. Шадунц (1898-1938) с 1935 по 1937 гг. был первым секретарем Центрального комитета коммунистической партии большевиков Таджикистана. В ноябре 1937 г. был арестован и уже 21 апреля 1938 г. был расстрелян в Московской области (Из Википедии).

${ }^{2}$ Шорахматуллоев А.А. (1963-2002) - известный шугнано-рушаноязычный поэт, журналист и бард, писал свои стихи под псевдонимом Лидуш Хабиб. 
рое было опубликовано в газете «Адабиёт ва санъат» («Литература и искусство») в 1990 г. В нем памирские языки были названы диалектами (Обращение 1990). Правда, авторы обращения не уточняют, диалектами какого языка они являются. Возможно, они имели в виду диалекты таджикского языка. Но тогда необходимо напомнить, что таджикский язык принадлежит к западной группе иранских языков, а памирские языки - к восточной, что заведомо исключает их диалектную принадлежность к таджикскому. Здесь мы опять видим, как культурно-языковые проблемы приобретают, используя термин известного российского социолога Л.М. Дробижевой, «политико-идеологическое звучание» (Дробижева 1989: 45). Как часто водилось в те годы, партийные руководители любую борьбу против кого-то или чего-то начинали руками самих жертв. Так, 24 июня 1988 г. сразу в трех республиканских газетах на трех языках (таджикском, русском и узбекском) появилось открытое письмо ветеранов войны и труда из ГБАО. В нем ветераны однозначно выступали против публикации газет и журналов на памирских языках. По их мнению, нет «никакой необходимости создавать газеты и другие издания на памирских языках» (Открытое письмо 1988). Чтобы дать полную свободу действий компартии для борьбы с теми, кто стремился к возрождению памирских языков, ветераны закончили свое письмо просьбой к Центральному Комитету Компартии Таджикистана «поставить прочный заслон нездоровым суждениям среди научных работников и творческой интеллигенции всеми средствами политического и идеологического воздействия» (Там же). Печально, что многие из подписавших это письмо ветеранов прекрасно знали, как партия может политическими средствами воздействовать на провинившихся людей, и творческую и научную интеллигенцию спасло то, что это были годы горбачевской перестройки, а не сталинских репрессий.

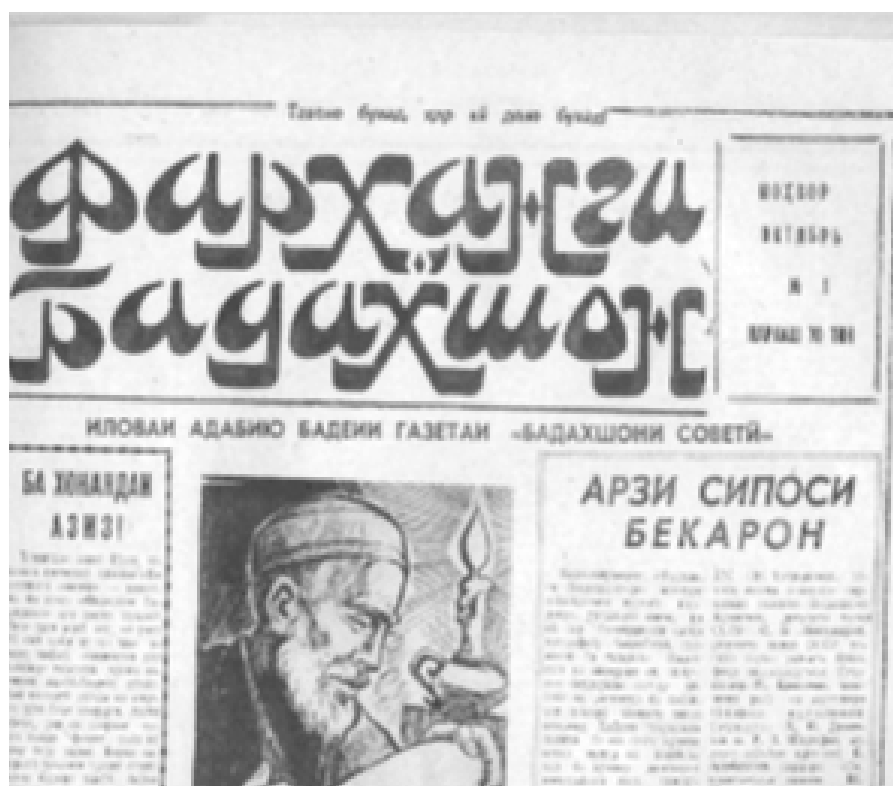

Рис. 12. Первый номер ежемесячника «Культура

Бадахшана» (из личного архива автора).

Несмотря на такие возмущенные письма «с мест», с октября 1990 г. начало выходить ежемесячное литературно-художественное приложение к газете «Бадахшони Советӣ» («Советский Бадахшан») - «Фархуанги Бадахшон» («Культура Бадахшана»). Данное приложение буквально с первого номера нашло живой отклик у читателей. В нем печатали стихи, рассказы, сказки разных памирских народов на их языках. Чтобы купить свежий номер «Культуры Бадахшана» в газетных киосках Хорога или Душанбе, надо было отстоять очередь.

Учитывая такую популярность, уже через год после основания в сентябре 1991 г. «Культура Бадахшана» стала самостоятельной газетой художественно-литератур- 
ного направления. Но, к сожалению, начало гражданской войны в РТ прекратило публикацию этой газеты ${ }^{1}$.

Забота о сохранении своего языка, по сути, является естественной реакцией любого этноса, и прав российский этнолог С.В. Чешко: «Каждый этнос, подобно другим видам социальных общностей, вырабатывает собственные интересы, отражающие его потребности: потребность в воспроизводстве - воспроизводстве биологическом и воспроизводстве своих сущностных характеристик (язык, культура, самосознание), потребность в развитии, потребность в защите от поглощения другими этносами и многие другие, производные от этих основных потребностей» (Чешко 1988: 70; об отстаивании этнокультурной самобытности памирских народов идет речь в другой статье данного автора: Чешко 1990: 123). Кстати, один из основателей Таджикской ССР, а ныне Герой Таджикистана Шириншо Шотемур в личной анкете при поступлении в Коммунистический университет трудящихся Востока им. И.В. Сталина в 1927 г. своим родным языком называл шугнанский.

Важное значение для сохранения и изучения памирских языков и памирского фольклора имело создание в декабре 1967 г. на базе Института языка и литературы им. Рудаки АН РТ сектора памирских языков. Его главным вдохновителем и создателем был профессор Д.К. Карамшоев (1932-2007)². В 1974 г. сектор преобразовали в отдел памирских языков, где начали систематически изучать памирские языки и фольклор. Были опубликованы десятки научных монографий и сотни статей по истории и грамматике памирских языков, по фольклору памирских народов и т.д. (Подробнее об этом см.: Юсуфбеков, Офаридаев 2013: 6-11). С 1991 г. после создания Института гуманитарных наук АН РТ в Хороге, административном центре ГБАО, данный отдел вошел в состав нового института, и успешно продолжает свою работу в настоящее время.

В постперестроечные времена в на-

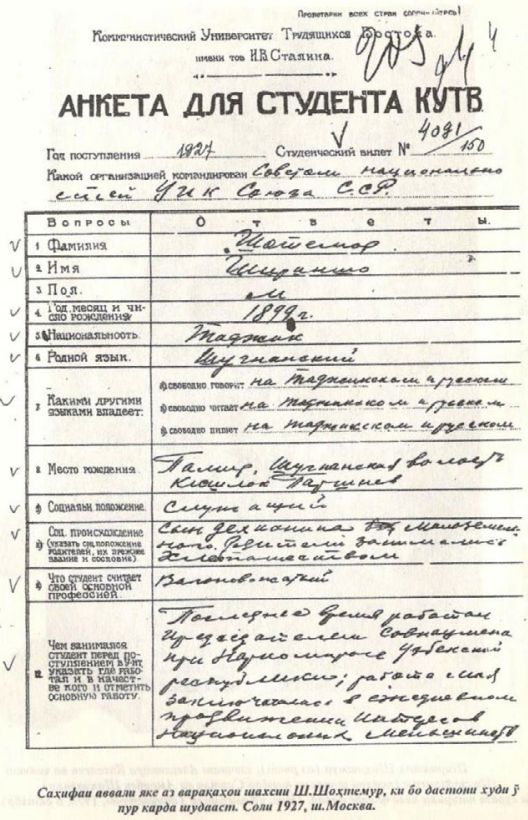

Рис. 13. Анкета (из книги Аламшох К. Где бы ни был с таджиками). учных центрах Москвы и Душанбе исследователи вернулись к проблеме памирских языков. Так, 30-31 марта 1989 г. в Институте языкознания АН СССР проходило заседание Круглого стола, посвященное изучению языков малочисленных народов СССР. Там выступили известные лингвисты - выходцы из ГБАО: Д.К. Карамшоев,

\footnotetext{
${ }^{1}$ Следует отметить, что другая газета ГБАО - «Коммунист Шугнана» тоже имела свое ежемесячное литературно-художественное приложение «Маърифат» («Просвещение»), первый номер которого вышел в апреле 1991 г.

2 Заметным вкладом в мировую иранистику можно считать трехтомный шугнанско-русский словарь Д. Карамшоева, а также его русско-шугнанский словарь и словарь памирских личных имен (см.: библиографию в конце данной статьи).
} 
Р.Х. Додыхудоев и П.Д. Джамшедов. В своих выступлениях все трое коснулись вопроса переписи 1989 г., в которой, как известно, памирские народы не учитывались. По мнению Д.К. Карамшоева, «следовало бы провести новую перепись для малочисленных народов. Необходимы также правовые гарантии автономии Горно-Бадахшанской автономной области, прежде всего, гарантировать право свободного функционирования памирских языков, для которых необходимо создание (восстановление) письменностей» (Колесник 1990: 187). Р.Х. Додыхудоев, говоря о недостатках переписи 1989 г., отмечал, что «на основе заведомо неверных данных формируются принципиальные решения в области языковой политики, например, утверждается “ненужность” образования на памирских языках» (Там же: 187). П.Д. Джамшедов выступил за создание «условий для функционирования языков в сфере массовой коммуникации, газет, радио» (Там же: 188).

Только в 1990-е гг. на Памире вернулись к вопросу об алфавите для памирских языков. Правда, дальнейшего развития письменность на базе латинской графики не получила (Эдельман, Юсуфбеков 2000: 226). В 2000 г. Институт гуманитарных наук Памирского филиала Академии наук Республики Таджикистан подготовил и выпустил «Букварь памирских языков на основе таджикского алфавита и русской графики» (Карамшоев 2000). Ранее автор этого букваря Д. Карамшоев вместе со своим учеником М. Аламшоевым издал «Букварь шугнанского языка» (Карамшоев, Аламшоев 1996). В 2000 г. они совместно издали «Учебник шугнанского языка для 2-4 классов» (Карамшоев, Аламшоев 2000). Попытки создания алфавита для памирских языков предпринимались и в Москве. Так в 2013 г. под руководством сотрудника

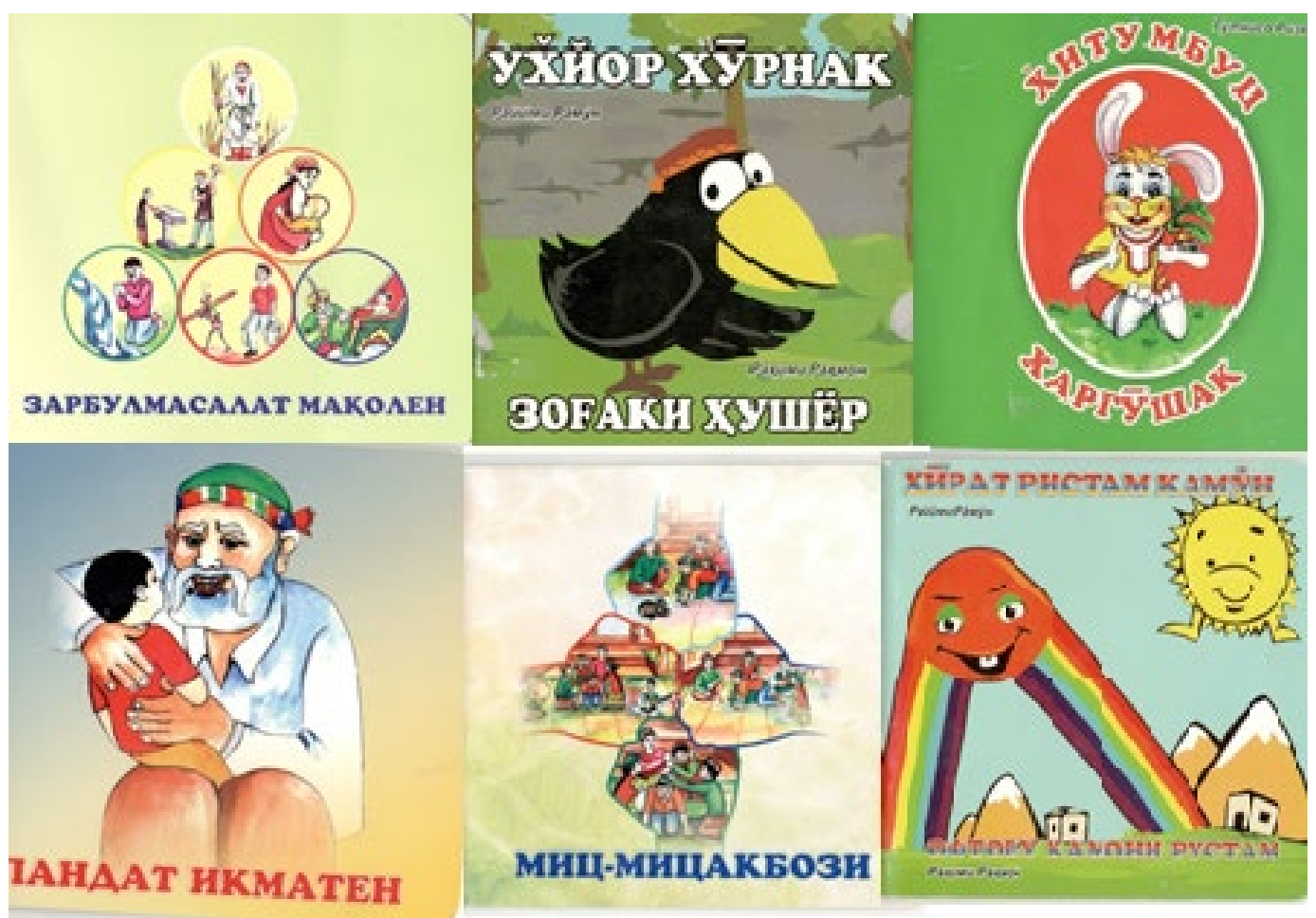

Рис. 14. Обложки детских книг на шугнанском языке (из личного архива автора). 
сектора иранских языков Института языкознания РАН Б.Б. Лашкарбекова (1948-2014) был организован семинар, где помимо сотрудников сектора участвовали поэты и писатели - выходцы из ГБАО, которые пишут на памирских языках. На семинаре они выступили за создание алфавита для памирских языков на основе кириллицы (Эдельман 2016: 104).

Справедливости ради надо отметить, что в последние годы в РТ появляются книги для детей на памирских языках. Практически во всех этих книгах используется таджикский алфавит с небольшими изменениями добавлены диграфы, линейки над буквой и т.д. Примером таких книг для детей может послужить сказание «Рассказы Равшана» известного шугнано-таджикского поэта Ато Мирходжа на шугнанском языке (Мирходжа 2010). Многое для сохранения памирских языков делает неправительственная организация «Нур» с цен-

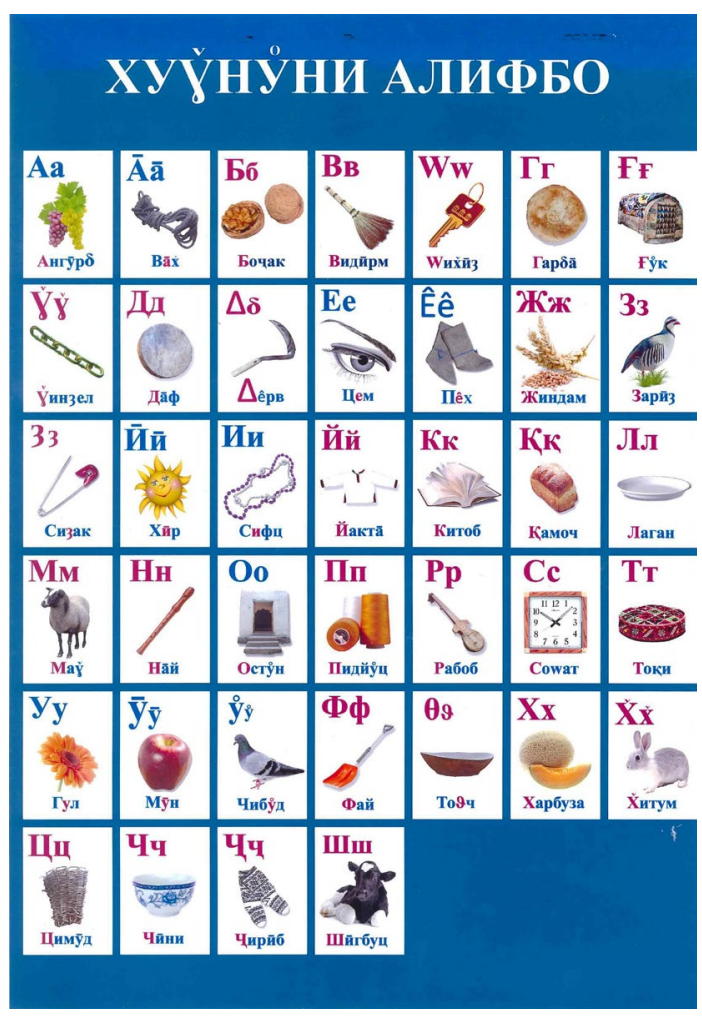

Рис. 15. Шугнанский алфавит (из личного архива автора). тром в сельском совете Поршиневе в

ГБАО. С 2013 г. по сегодняшний день она выпустила больше 20 детских книжек на памирских языках. Для примера, приведем фотографий обложок некоторых из них:

При написании этих детских книжек авторы использовали шугнанский алфавит на основе криллицы.

При непосредственном содействии «Нур» был опубликован первый роман на шугнанском языке «Зиндаги аз нав ия су̀d сар» («Если бы жизнь началась заново») молодого писателя Худобахша Худобахшова. В предисловии автор говорит о ценности памирских языков и задается вопросом: что он сам может сделать, чтобы помочь родному языку? Отсюда его намерение написать книгу на шугнанском языке. И еще его цель, сформулированная там же, чтобы «... у наших памирцев были наши Лейли и Меджнун или Ромео и Джульетта. Но не похожие на них, а чисто наши, памирские» (Худобахшов 2017: 4).

Главные герои данного романа четыре друга - Барзу, Саид, Расул и Насим - попадают в разные истории в городе Хорог и его окрестностях. Любовь Барзу и Алии проходит красной нитью по всему роману. Конечно, и до этого романа издавалась проза на шугнанском языке, но все предыдущие публикации - переводы с русского языка. Например, переведены с русского языка произведения В. Гауфа «Маленький Мук» и Л. Кассиля «Льдина-холодина». Был подготовлен, но не издан перевод романа М. Горького «Мать» (Эдельман 2017: 191). 


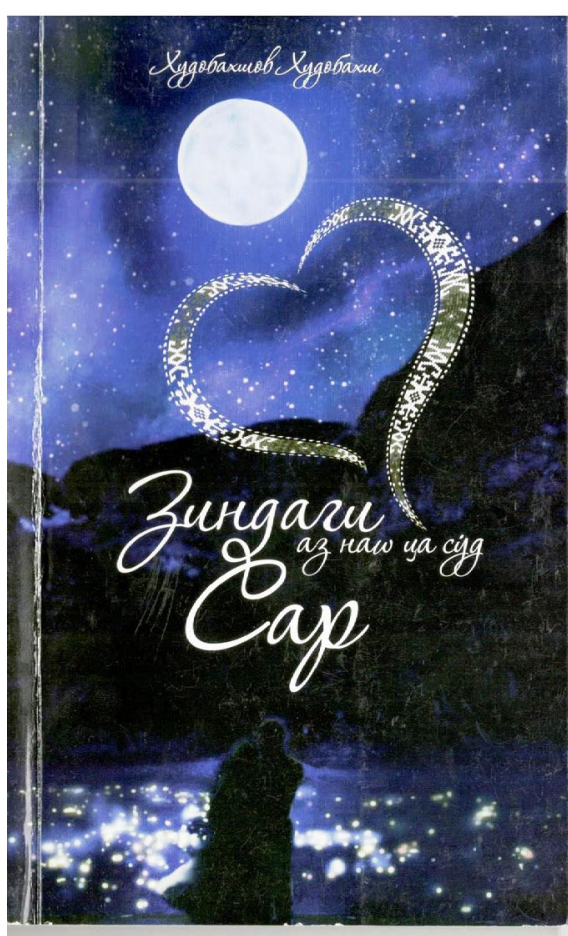

Рис. 16. Обложка первого авторского романа на шугнанском языке (из личного архива автора).
В октябре 2009 г. в Хороге вышел первый номер ежемесячной газеты «Лозар» (в переводе с шугнанского: «Ледник»). Газета планировала публиковать стихи, рассказы, фольклорные произведения на памирских языках. Однако, к сожалению, были изданы только 7 номеров газеты, так как, по словам ее главного редактора известного шугнано-таджикоязычного поэта Хушомада Алидодова, спонсорам газеты было «рекомендовано» прекратить свою помощь изданию (ПМА 2016).

В 2019 г. в Душанбе вышла книга «Иссохшее дерево в пустыне» - перевод стихов Лидуша Хабиба с шугнанского языка на русский язык.

Переводчиком стихов выступил Исфандиёр Неккадамов (1978-2015). Судя по переводам, к сожалению, рано ушедший от нас Исфандиёр Неккадамов, был талантливым поэтом и переводчиком. Он очень мастерски перевел стих-исповедь Лидуша, которое называется «сорок лет»: Wузум вих̄̄u тар ху маорат навирудху,

Ба̄д аз ху маорат йе̂ роат навирӯдху. Роат ме дунйо-теิ йе̂ соат навирӯдху, Дунчат малол аз ху хайолат меิ ху олум. Мундеิ му маорат му чӯд йор пеิ бало ху, Аз дастеิ шаробеิ му чуд ғарқе̂ гуноху,

Ба̄деิ му шароб зиндагийанд чуд му фаноху.

Чизард? Wуз айрӯн хубас аз ху сашолум.

Wузум гуму̊н чӯд йам умреิ дарозху,

Ба̄дум на ху дунд чӯд сироқат, на ху созху, Арчондиен лу̊д - зишостум ху аwозху

Шич аз йичийаv най хубаv аз ху малолум.

Шич-та сафар шуз муқобилеิ шамолум, Чил сол бакор мурд йчой пур та ху солум, Ба̄д-та азаманд шуз ху чил ар ху чушолум, Мурд зеб набед пастеิ, шуз шоире̂ болум.

\section{Сорок лет}

Я к своему таланту ключ не находил,

И мой талант мне наслажденье не дарил.

Поиск покоя в жизни сердце мне разбил.

И лишь поэтому обиду я на судьбу свою держу.

С талантом в жизнь свою ненастья запустил.

С грехами в озере вины меня он утопил.

Вино же меня куда-то в бездну заносило.

За что? Увы, ответ, друзья, не находил.

Я был уверен: в мире этом жить долго и вечно буду.

И не берег себя, стихи свои я разбросал повсюду.

И на просьбу «спой» - я исполнял везде, простому люду. 
И только на себя обиду я держу.

Сейчас же против ветра в жизни я иду.

Мне сорок лет нужны, их где-то соберу.

И лишь, потом, расправив крылья полечу.

Небесный я поэт! Лишь небу я принадлежу (Иссохшее дерево 2019: 46-47).

В этой же книге опубликованы несколько рубаи и одно стихотворение поэта и переводчика Исфандиёра Неккадамова на русском языке. Приведем один из рубаи Исфандиёра:

Покинули сей бренный мир десяток сотен душ:

Хайям, Руми, Рустам, Сухроб, Джами и Сиявуш...

Их с нами нет, но в сердце их имена остались,

Подобно им в сердцах памирцев был высечен - Лидуш (Там же: 14).

Следует признать, что в советское время, кроме 1930-х гг., было мало публикаций на памирских языках. Более того, в 1972 г. прошла кампания по уничтожению книг на памирских языках в Государственной публичной библиотеке им. Фирдоуси в Душанбе. Это остается «черным пятном» в истории культурной жизни Таджикистана. Прав М.И. Исаев, который писал: «О пренебрежительном отношении к культурным запросам малочисленных народов говорит и такой факт, как уничтожение (т.е. в 1972 г.) чудом сохранившихся шугнанских книг. Ретивые деятели хотели выжечь из памяти страницы истории развития культуры памирских народов» (Исаев 1990: 98; ср.: Додыхудоев 1991:6). По сведениям М.Ю. Мартыновой к концу 1970-х гг. образование можно было получить лишь на 14 языках народов СССР (Мартынова 2020: 45).

Пренебрежение к естественным потребностям людей в сохранении и развитии родного языка часто приводит к радикальным последствиям. Одной из причин принятия Декларации о преобразовании ГБАО в Автономную республику Бадахшан (Памир) в составе Республики Таджикистан (10 апреля 1992 г.) была попытка сохранить памирские языки от исчезновения ${ }^{1}$.

Сохранение памирских языков, существование которых находятся под угрозой, является общественно значимым делом. Специалистами в этой области сформулированы практические советы по сохранению таких языков (К примеру, см.: Замятин и др. 2012: 133-162), которые могли бы быть полезны для сбережения и развития памирских языков. Тем более что, по справедливому замечанию С.А. Арутюнова, «каждый язык вне зависимости от уровня развития его носителей имеет потенциальную возможность развиться в современный язык» (Арутюнов 2005: 160).

Одним из спасителей малых языков от исчезновения выступает Интернет. В социальных сетях уже существуют специальные сообщества, или группы, под названиями «Таджикская поэзия» и «Памирская поэзия». Входящие в них авторы публикуют произведения на собственных страничках, имеют подписчиков в Интернете и получают от них «лайки» или комментарии. Считается, чем больше «лайков» получает автор, тем более популярным он стал среди пользователей соцсетей. Кроме этого в Ютубе имеется большое количество видеороликов с песнями и стихами на памирских языках. Если в первом случае авторы-поэты вынуждены фиксировать свои произведения письменно (для этого чуть ли ни каждый из них «изобретает» свой алфавит, так как общего официального алфавита не существует не только на общепамирском уровне, но и для отдельных языков), то для Ютуба достаточно в уст-

\footnotetext{
${ }^{1}$ Здесь мы не касаемся этой темы и отсылаем читателя к статье: Худоёров 2011: 78-81.
} 
ной форме продекламировать или спеть свои произведения (о развитии авторской поэзии на шугнанском и рушанском языках см. Охонниёзов 2017).

Хотелось бы подчеркнуть, что поэтическое творчество является не только средством самовыражения, но и поводом для коммуникации земляков в виртуальном пространстве. Очень часто после появления очередного продукта поэтической формы в этих соцсетях происходит достаточно бурное обсуждение и появляются многочисленные комментарии. Как правило, все это тоже происходит на памирских языках. Если, к примеру, стих на ваханском языке, то обсуждение и комментарии осуществляются на ваханском языке, если письменные и видео материалы на шугнанском языке, то соответственно вся дальнейшая дисскуссия тоже ведется на шугнанском языке и т.д. Таким образом, социальные сети Интернета выступают той благодатной площадкой, где соединяются воедино субъективные желания и амбиции автора стихов, с одной стороны, и технические возможности быть замеченным широкой аудиторией - с другой. Таким образом, на примере шугнанского языка подтверждаются слова Э. Хобсбаума о том, что «мы больше не живем исключительно в культуре чтения и письма» (Hobsbawm 1997: 90). Когда-то выдающиеся иранисты А.Л. Грюнберг и И.М. Стеблин-Каменский с сожалением констатировали, что «к немалому ущербу для науки шугнанский поэтический фольклор, как и личное творчество шугнанских народных поэтов, почти не изучался и не записывался» (Сказки... 1976: 9). Сегодня Интернет дает эту возможность носителям бесписьменных языков записывать и передавать материалы на этих языках практически в любую точку земного шара.

Появились большое количество шугнаноязычных поэтов, которые в социальных сетях, таких как Facebook или Одноклассники, выкладывают свои стихи в текстовом формате, а также в формате аудио- и видеофайлов. Достаточно перечислить нескольких авторов: это Абдулназаров А., Абдурахмонов Б., Акдодов Ф., Бахтибеков А., Давлатов А., Давлатов И., Дилбаршо М., Заифи С., Охонниёзов В., Мирзохасанов Л., Мирходжа А., Мубориз Р., Назаров К., Ризвоншо Г., Рустамбеков А., Рустамбек А., Шохин М., Шукриллоев А. и другие.

Трагическое событие 10 сентября 2019 г. - публичное самосожжение удмуртского ученого и общественного активиста Альберта Разина перед зданием парламента Удмуртии всколыхнуло российское общество. Разин пожертвовал собой ради сохранения удмуртского языка, и, судя по его последним словам, таким образом хотел привлечь внимание к проблеме «вымирания» удмуртского языка. На одном из двух плакатов, которые Разин развернул в своем одиночном пикете, было написано: «И если завтра мой язык исчезнет, то я готов сегодня умереть». И он умер! После смерти Разина споры и дискуссии о государственной политики России относительно миноритарных языков разгорались не только на общественных площадках, но и среди ученого сообщества. Диалог В.А. Тишкова и Х.М. Акбаева о конфликте вокруг родного языка относится к таковым (Тишков, Акбаев 2020: 19-39). Дело в том, что многие общественные и политические активисты, а иногда и ученые поддерживают тезис о том, что смерть языка означает смерть этноса. Академик В.А. Тишков в газете «Известия» 12 сентября 2019 г. опубликовал свое сообщение под названием, данным редакцией: «Народ не умирает с языком», где он поддерживает тезис о том, что «смерть языка не означает смерть народа». На такое высказывание ему оппонировал карачаевский филолог и член Союза писателей России Харун Акбаев, который, наоборот причисляет себя к сторонникам тезиса «умер язык-умер народ» (Там же: 19). 
В преамбуле конституционного закона Республики Таджикистан о Горно-Бадахшанской автономной области (подписан Президентом РТ 30 июля 2007 г.) сказано, что ГБАО наряду с другими ценностями географического и культурного характера обладает также «уникальными языковыми ценностями» (Конституционный закон 2007).

Когда-то замечательный русский поэт П.А. Вяземский (1792-1878) в своем стихотворении «Англичанке» написал такие строки:

Язык есть исповедь народа:

В нем слышится его природа,

Его душа и быт родной... (Вяземский 1958: 331)

Тысячелетняя история памирских таджиков сохранилась в устной форме, и она передается от поколения к поколению. Хочется верить, что культуротранслирующая функция этих языков будет сохраняться еще долго.

\section{Источники и материалы}

Амдинов 1936 - Амдинов С. Колхозчй (Колхозник) // Бадахшони сурх (Красный Бадахшан) от 30 апреля 1936 г. (на таджикском яз).

Вяземский 1958 - Вяземский П.А. Стихотворения. Л.: Советский писатель, 1958.

Дузд йурххак 2014 - Дузд йурххк / Фарохуамоваранда Гулнисо Ризвоншоева / Мухуаррир Ато Мирхоч̨а (Медвежонок-вор / Составитель Гулнисо Ризвоншоева / отв. ред. Ато Мирходжа). Хорог, 2014 (на шугнанском яз).

Закон 2009 - Закон Республики Таджикистан о государственном языке Республики Таджикистан от 5 октября 2009 года.

Зарбулмасалат 2014 - Зарбулмасалат мақолен / Фарохамоваранда Гулнисо Ризвоншоева / Мухаррир Ато Мирхоча (Пословицы и поговорки / Составитель Гулнисо Ризвоншоева / Отв. ред. Ато Мирходжа). Хорог, 2014 (на шугнанском яз).

Искандаров, Амдинов 1933 - Искандаров Б., Амдинов С. Забони модари китоб. Ибтидойи мактабенард. Соли биунум чат (Учебник родного языка для второго класса. Сталинабад: Государственное изд-во Таджикистан, 1933).

Иссохшее дерево 2019 - Иссохшее дерево в пустыне. Составитель Гулям Х. Душанбе, 2019. Карамшоев 2000 - Карамшоев Д. Алифбои забонхои помирй. (Букварь памирских языков). Хорог, 2000 (на тадж. и шугнан. яз).

Карамшоев, Аламшоев 1996 - Карамшоев Д., Аламшоев М. Алифбои забони шуғнонй (Букварь шугнанского языка). Душанбе: Маориф, 1996 (на тадж. и шугнан. яз).

Карамшоев, Аламшоев 2000 - Карамшоев Д., Аламшоев М. Китоби дарси синфени 2-4. (Учебник шугнанского языка для 2-4 классов). Хорог: Помир, 2000.

Карим 1938 - Карим Х. Хейдов китоб. Якум қисм. (Книга для чтения. Первая часть). Сталинабад: Учебно-педагогическое изд-во Тадж. ССР, 1938.

Хуршеди Хамдам 2017 - Хуршеди Хамдам, Шахлои Гулходжа Комитет по языку: «Спасем от исчезновения памирский и ягнобский языки» // http://rus.ozodi.org/a/27156356.html (дата доступа: 01.03.2017).

Конституционный закон 2007 - Конституционный закон Республики Таджикистан о ГБАО // Бадахшон. 3 августа 2007 г. (на тадж. яз).

Лалайик 2014 - Лалайик / Фарохуамоваранда Гулнисо Ризвоншоева / Мухฺаррир Ато Мирхочза (Колыбельная / Составитель Гулнисо Ризвоншоева / Отв. ред. Ато Мирходжа). Хорог, 2014 (на шугнанском яз).

Мирходжа 2010 - Мирходжа А. Равшан қиссаен (Рассказы Равшана) Душанбе: Адиб, 2010 (на шугнанском яз).

Миц-мицакбози 2014 - Миц-мицакбози / Фарохамоваранда Гулнисо Ризвоншоева / Мухаррир Ато Мирхоча (Игра миц-мицак) Составитель Гулнисо Ризвоншоева / отв. ред. Ато 
Мирходжа). Хорог, 2014 (на шугнанском яз).

Народность 1928 - Народность и родной язык населения СССР. Издание ЦСУ СССР. М.,1928.

Обращение 1990 - Обращение к народным депутатам // Адабиёт ва санъат. (Литература и искусство) 22 ноября 1990 г. (на тадж. яз.).

Открытое письмо 1988 - Открытое письмо // Коммунист Таджикистана. 24 июня 1988 г.

Охонниёзов 1998 - Охонниёзов В.Д. Ифтихори шеьри шуғнй (Гордость шугнанской поэзии) // Шанбезода Н. Гулгунча (Бутон). Хорог: “Помир”, 1998. С. 5-18.(на тадж. яз.)

Пандат икматен 2014 - Пандат икматен / Фарохамоваранда Гулнисо Ризвоншоева / Мухаррир Ато Мирхоча (Наставление и мудрости) Составитель Гулнисо Ризвоншоева / Отв. ред. Ато Мирходжа). Хорог, 2014 (на шугнанском яз).

ПМА 2019 - Полевые материалы автора. Экспедиции в город Хорог Республики Таджикистан, сентябрь 2016 г. Экспедиции в Шугнанский и Рошткалинский районы Республики Таджикистан, август 2019 г.

Сказки народов 1976 - Сказки народов Памира / Пер. с памирских языков. Сост. и коммент. А.Л. Грюнберга, И.М. Стеблин-Каменского. М., 1976.

Советские писатели 1949 - Советские писатели Таджикистана. Биографические справки. Сталинабад: Таджикгосиздат, 1949.

Ух்йор хӯрнак 2014 - Ух்йор хӯрнак / Фарохамоваранда Рахими Рахмон / Мухаррир Ато Мирхоча (Бдительная ворона). Составитель Рахими Рахмон / Ато Мирходжа). Хорог, 2014 (на шугнанском яз).

Фортунатова 1937 - Фортунатова К.A. Китоб хейдов чат. Синфи буйуонум мактабени ибтидойи рад (Книга для чтения. Для второго класса начальной школы). Сталинабад: Учебно-педагогическое изд-во Тадж. ССР, 1937 т (на шугнанском яз).

Хӣрат ристамкаму̊н 2014 - Хӣрат ристамкаму̊н / Фарохамоваранда Рахими Рахмон / Мухаррир Ато Мирхоча (Радуга). Составитель Рахими Рахмон / Ато Мирходжа). Хорог, 2014 (на шугнанском яз).

Худобахшов 2017 - Худобахшов $X$. Зиндаги аз нав ца су̊д сар (Если бы жизнь началась заново) Хорог, 2017 (на шугнанском яз).

Хитумбуц 2014 - Х्Хитумбуц / Фарохамоваранда Гулнисо Ризвоншоева / Мухаррир Ато Мирхоча (Зайчонок). Составитель Гулнисо Ризвоншоева / Отв. ред. Ато Мирходжа). Хорог, 2014 (на шугнанском яз).

Х̄̄̄чат марка̄б 2014 - Х्Х̄̄чат марка̄б / Фарохамоваранда Гулнисо Ризвоншоева / Мухаррир Ато Мирхоча (Бык и осел). Составитель Гулнисо Ризвоншоева / Отв. ред. Ато Мирходжа). Хорог, 2014 (на шугнанском яз).

Чисту̊н ма чисту̊н 2014 - Чисту̊н ма чисту̊н / Фарохамоваранда Гулнисо Ризвоншоева / Мухаррир Ато Мирхоча (Загадки). Составитель Гулнисо Ризвоншоева / Отв. ред. Ато Мирходжа). Хорог, 2014 (на шугнанском яз).

Шамбезода 1937 - Шамбезода Д. Алифбе. Аввалун солард (Букварь для первого года обучения). Сталинабад: Учебно-педагогическое изд-во Тадж. ССР, 1937 (на шугнанском яз).

Шамбезода 1937 - Шамбезода, Мусрифиоев, Бандишоев. Хубнуни алифбе. Ғулайен чат (Букварь для взрослых на шугнанском языке). Сталинабад: Таджикское государственное изд-во, 1931.

Шонаврузов 1936 - Шонаврузов 3. Ба муносибати кишти бахории болшевикй (В честь весеннего большевистского посева) // Бадахшони сурх (Красный Бадахшан) от 30 апреля 1936 г. (на таджикском яз).

Шонаврузов 1931 - Шонаврузов 3. Хубнуни алифбе. Кудакен чат (Букварь для детей). Сталинабад: Государственное изд-во Таджикистан, 1931 (на шугнанском яз).

Шорахматуллоев 1990 - Шорахматуллоев Л. Нужны конкретные дела. Родной язык: дебаты и дискуссии // Бадахшони Советй (Советский Бадахшан). 9 августа 1990 г.

Шукрат натича 2014 - Шукрат натича / Фарохамоваранда Гулнисо Ризвоншоева / Мухаррир Ато Мирхоча (Дар благодарности). Составитель Гулнисо Ризвоншоева / Отв. ред. Ато 
Мирходжа. Хорог, 2014 (на шугнанском яз).

\section{Научная литература}

Абдулназаров А.А. Сатира в творчестве Нодира Шанбезаде // Молодой ученый, 2012. № 1. Т. 2. C. 9-13.

Аламшоев М. Историческое становление и перспективы сохранения памирских языков// Endangered languages and History / Ed. by H. Elnazarov, N. Ostler. FEL. England, 2009. Pp. 177-182.

Аламшох К. Кучое бошам бо точикон бошам (Где бы ни был с таджиками) Душанбе: Ирфон, 1999 (на таджикском яз).

Арутюнов C.[A]. Этнические процессы и язык // Герд А.С. Введение в этнолингвистику: Курс лекций и хрестоматия. 2-е изд., исправ. СПб.: Изд-во Санкт-Петербургского университета, 2005. С. 155-174.

Баходур Искандаров - ученый, педагог и воин. Материалы научно-теоретической конференции, посвященной 100-летию со дня рождения академика Б. Искандароа (г. Душанбе, 14 ноября 2012 г.). Душанбе: Дониш, 2013.

Бухерт В.Г. Настоятельнейщие нужды памирского района. Записка И.И. Зарубина. 1917 г. // Восточный архив, 2011. № 2. С. 30-32.

Грюнберг А.Л., Стеблин-Каменский И.М. Несколько замечаний по поводу отклика А.С. Давыдова на статью С.В. Чешко // Советская этнография, 1989. № 5. С. 35-38.

Губогло М.Н., Сафин Ф.Г. Принудительный лингвицизм. Социолингвистические очерки об этнополитической ситуации в СССР в 1920-1930-е годы. М.: ЦИМО, 2000.

Додыхудоев Р.X. Языковая политика и языковое строительство в Таджикистане // Русский язык в СССР, 1991. № 9. С. 5-7.

Додыхудоева Л.Р. Памирские языки // Языки мира: иранские языки. Вып. III. Восточноиранские языки. М.: Индрик, 2000. С. 170-174.

Дробижева Л.М. О проблемах межнациональных отношений и задачах этносоциологии в современных условиях // Советская этнография, 1989. № 1. С. 41-47.

Дьяков А.М. Языки советского Памира // Культура и письменность Востока. Книга Х. М.: ВЦК НА, 1931. С. 85-90.

Залеман К.Г. Шугнанский словарь Д.Л. Иванова // Восточные заметки. Сборник факультета восточных языков. СПб., 1895.

Замятин К., Пасанен А., Саарикиви Я. Как и зачем сохранять языки народов России? Хельсинки, 2012.

Зарубин И.И. Два образца припамирской народной поэзии // Отд. Оттиск из Доклады Российской Академии наук. М., 1924. С. 177-180.

Зарубин И.И. Список народностей Туркестанского края. Ленинград, 1925.

Зарубин И.И. Шугнанские тексты и словарь. М.; Л.: Изд-во Академии наук СССР, 1960.

Исаев М.И. Языки малочисленных народов СССР: Проблемы функционирования и сохранения) // Национально-языковые проблемы: СССР и зарубежные страны / Отв. ред. К.В. Бахнян. М.: ИНИОН АН СССР, 1990. С. 85-100.

Карамшоев Д.К. Новое в памирской филологии // Вопросы языкознания, 1977. № 1. С. 126-133.

Карамшоев, Д. Шугнанско-русский словарь // под ред. А.Л. Грюнберга. Т. 1.. М.: Наука, 1991. Карамшоев, Д. Шугнанско-русский словарь // под ред. А.Л. Грюнберга. Т. 2. М.: Наука, 1991. Карамшоев, Д. Шугнанско-русский словарь // под ред. А.Л. Грюнберга. Т. 3. М.: Восточная литература, 1999.

Карамшоев Д. Русско-шугнанский словарь // под ред. И.М. Стеблин-Каменского. Т. 4. Душанбе: Главная научная редакция Таджикской национальной энциклопедии, 2005.

Карамшоев Д. Словарь памирских личных имен // под ред. Ш.П. Юсуфбекова. Т. 5. Душанбе: Дониш, 2015.

Колесник Н.Г. Языки малочисленных народов СССР: Состояние и перспективы (Материалы 
«круглого стола», март 1989 г.) // Национально-языковые проблемы: СССР и зарубежные страны. М., 1990. С. 178-194.

Костомаров В.Г. Еще раз о понятии «родной язык»// Русский язык в СССР, 1991. № 1. C. 9-15.

Мандельштам А.М. Материалы к историко-географическому обзору Памира и Припамирских областей. Сталинабад, 1957.

Мартынова М.Ю. Язык и школьное образование. Российский опыт // Смерть языка - смерть народа? Языковые ситуации и языковые права в России и сопредельных государствах / отв. ред. Е.И. Филиппова и С.С.Соколовский. М.: Горячая линия - Телеком, 2020. С. 40-74.

Моногарова Л.Ф. Ассимиляция и консолидация памирских народов // Среднеазиатский этнографический сборник. Вып. IV / отв. ред. В.И. Бушков. М.: Наука, 2001. С. 47-55.

Охонниёзов В.Д. Нодир Шамбезода ва адабиёти муосири точик (Нодир Шамбезода и современная таджикская литература). Душанбе, 2012 (на таджикском яз).

Охонниёзов В.Д. Пайдоиш ва ташаккули шеьри муаллифй ба забонхои помирй (дар мисоли гурухи забонхои шуғнонй-рушонй). Мухаррири масъул профессор Н. Шакармамадов (Возниконовение и развитие авторской поэзии на памирских языках (на примере шугнанского и рушанского языков // отв. ред. Профессор Н. Шакармамадов). Душанбе: Эр-граф, 2017 (на таджикском яз).

Пахалина Т.Н. Памирские языки. М.: Наука, 1969.

Рождественский Ю.В. Лекции по общему языкознанию. М.: Академкнига, 2002.

Солнцев В.М., Михальченко В.Ю. Языковая ситуация в СССР // Национально-языковые проблемы: СССР и зарубежные страны. М.: ИНИОН АН СССР, 1990. С. 14-31.

Сюань-изан. Записки о западных странах [эпохи] Великой Тан (Да Тан си юй изи)/ Введ. пер. и коммент. Н.В. Александровой. М.: Восточная литература, 2012.

Тишков B.A. Родной язык // Этнокультурный облик России: перепись 2002 года / отв. ред. В.В. Степанов, В.А. Тишков. М.: Наука, 2007. С. 50-63.

Тишков В.А. Языки нации // Вестник российской академии наук, 2016. Том 86, № 4. С. 291-303.

Тишков B.A., Акбаев X.M. «Народ не умирает с языком» или «Язык не живет без народа». Диалог ученых о конфликте вокруг родного языка // Смерть языка - смерть народа? Языковые ситуации и языковые права в России и сопредельных государствах / отв. ред. Е.И. Филиппова и С.С.Соколовский. М.: Горячая линия - Телеком, 2020. С. 19-39.

Худоёров М.М. Проблема памирской автономии в Таджикистане на рубеже 1980-1990-х годов // Вестник Челябинского государственного университета, 2011. Вып. 46. С. 78-81.

Худоназаров Д. Памирская одиссея благородного финна. Эдуард Кивикэс и таджики // Родина, 2008. № 4. С. 76-80.

Чешко С.В. Национальный вопрос в СССР: состояние и перспективы изучения // Советская этнография, 1988. № 4. С. 62-72.

Чешко С.В. Средняя Азия и Казахстан: современное состояние и перспективы национального развития // Расы и народы, 1990. № 20. С. 106-127.

Шамбезода Х.Д. Функционирование бесписьменного языка малой народности в условиях полиэтнического социума (на материале шугнанского языка в таджикско-русском окружении). Диссертация на соискание ученой степени доктора филологических наук. Российско-таджикский (славянский) университет. Душанбе, 2007.

Шуғнон. Тахти назари академик М. Илолов ва профессор П. Чамшедов (Шугнан. Под общей редакции академика М. Илолова и профессора П. Джамшедова). Душанбе: Ирфон, 2014 (на таджикском яз).

Эдельман Д.И. Современное состояние изучения памирских языков // Вопросы языкознания, 1964. № 1. С. 128-138.

Эдельман Д.И. Некоторые проблемы миноритарных языков Памира (к становлению письменности и литературы) // Родной язык. Лингвистический журнал, 2016. № 2 (5). С. 87-113.

Эдельман Д.И. Роль культурных контактов в становлении письменной литературы на шугнан- 
ском языке // Развитие языков и литератур в контактных ситуациях. Материалы круглого стола. Отв. редакторы: В.Я. Порхомовский, И.И. Челышева. М.: Буки Веди, 2017. С. 189-201.

Эдельман Д.И., Юсуфбеков Ш.П. Шугнанский язык // Языки мира: Иранские языки. III. Восточноиранские языки. М.: Индрик, 2000. С. 225-242.

Энсиклопедияи Бадахшон (Энциклопедия Бадахшана). Душанбе: Андалеб Р. 2016 (на тадж. яз).

Юсуфбеков Ш.П. Миноритарные языки Памира: Проблемы и перспективы развития и изучения // Лексика, этимология, языковые контакты. К юбилею доктора филологических наук, профессора Джой Иосифовны Эдельман. Сборник статей. М.: Тезаурус, 2011. С. 278-282.

Юсуфбеков Ш., Офаридаев Н. Вместо предисловия // Вопросы памироведения. Выпуск 7. Душанбе, 2013. С. 6-11.

Fouse $G$. The languages of the former Soviet Republics; their history and Development. University press of America, Oxford, 2000.

Hobsbawm E. J. Are All Tongues Equal? Language, culture, and national identity // Living as Equals / Ed. by Paul Barker. Oxford: Oxford University Press, 1997. Pp. 85-98.

Morgenstierne G. Notes of Shughni // Norsk tidsskrift for sprogvidenskap.Bind 1. Oslo, 1928. Pp. 32-84.

Morgenstierne G. Indo-Iranian frontier languages. Vol. II. Iranian Pamirian Languages (Yidgha-Munji, Sanglechi-Ishkashmi, and Wakhi). Oslo, 1938.

Shaw R. On the Ghalchah Languages (Wakhi and Sarikoli) // Journal of the Asiatic Society of Bengal. Vol. XLV. Calcutta, 1876. Pp. 139-278.

\section{References}

Abdulnazarov, A.A. 2012. Satira v tvorchestve Nodira Shanbezade [Satire in the works of Nodir Shanbezade]. Molodoi uchenyi 1 (2): 9-13.

Alamshoev, M. 2009. Istoricheskoe stanovlenie i perspektivy sokhraneniia pamirskikh yazykov [Historical Formation and Perspectives for the Preservation of the Pamiri Languages]. In Endangered languages and History, edited by H. Elnazarov, N. Ostler, 177-182. Bath: Foundation for Endangered Languages.

Alamshokh, K. 1999. Gde by ni byl s tadzhikami [Wherever with Tajiks]. Dushanbe: Irfon.

Arutiunov, S.A. 2005. Etnicheskie protsessy i yazyk [Ethnic Processes and Language]. In Vvedenie $v$ etnolingvistiku: Kurs lektsii i khrestomatiia [Introduction to Ethnolinguistic: Lectures and Anthology], edited by A.S. Gerd, 155-174. St. Petersburg: Izdatel'stvo Sankt-Peterburgskogo universiteta.

Bukhert, V.G. 2011. Nastoiatel'nie nuzhdy pamirskogo raiona. Zapiska I.I. Zarubina. 1917 g. [The Urgent Needs of the Pamir Region. Note of I.I. Zarubin. 1917]. Vostochnyi arkhiv 2: 30-32.

Cheshko, S.V. 1988. Natsional'nyi vopros v SSSR: sostoianie i perspektivy izucheniia [The National Issue in the USSR: Status and Research Perspectives]. Sovetskaia etnografiia 4: 62-72.

Cheshko, S.V. 1990. Sredniaia Aziia i Kazakhstan: sovremennoe sostoianie i perspektivy natsional'nogo razvitiia [Central Asia and Kazakhstan: The Contemporary State and Prospects for the National Development]. Rasy i narody 20: 106-127.

D'iakov, A.M. 1931. Iazyki sovetskogo Pamira [Languages of the Soviet Pamir]. In Kul'tura $i$ pis'mennost' Vostoka. Kniga X [Culture and Writing of the East. Book X], 85-90. Moscow: VTsK NA.

Dodykhudoev, R.Kh. 1991. Yazykovaia politika i yazykovoe stroitel'stvo v Tadzhikistane [The Language Policy and Language Construction in Tajikistan]. Russkii iazyk v USSR 9: 5-7.

Dodykhudoeva, L.R. 2000. Pamirskie iazyki [Pamirin languages]. In Yaziki mira: Iranskie yazyki. III. Vostochnoiranskie yazyki [Languages of the World: Iranian Languages. III. Eastern Iranian Languages], edited by V.S. Rastorguev, 170-174. Moscow: Indrik.

Drobizheva, L.M. 1989. O problemakh mezhnatsional'nykh otnoshenii i zadachakh etnosotsiologii v sovremennykh usloviiakh [About Interethnic Relations and Tasks of Ethnic Sociology in Contemporary Conditions]. Sovetskaia etnografiia 1: 41-47. 
Edel'man, D.I. 2017. Rol'kul'turnykh kontaktov v stanovlenii pis'mennoi literatury na shugnanskom iazyke [The Role of Cultural Contacts in the Development of Written Literature in the Shugnani language. In Razvitie iazykov i literatur v kontaktnykh situatsiiakh. Materialy kruglogo stola [Development of Languages and Literatures in Contact Situations. Materials of the Round Table Discussion], edited by V.Ia. Porkhomovskii and I.I. Chelyshev, 189-201. Moscow: Buki Vedi.

Edel'man, D.I. 1964. Sovremennoe sostoianie izucheniia pamirskikh iazykov [The Current State of the Study of the Pamirian languages]. Voprosy iazykoznaniia 1: 128-138.

Edel'man, D.I. 2016. Nekotorye problemy minoritarnykh yazykov Pamira (k stanovleniiu pis'mennosti i literatury) [Some Problems of the Minority Languages of Pamir (on the Formation of the Written Language and Literature)]. Rodnoi yazyk. Lingvisticheskii zhurnal 2(5): 87-113.

Edel'man, D.I., and Sh.P. Yusufbekov. 2000. Shugnanskii yazyk [Shugnani language]. In Yaziki mira: Iranskie yazyki. III. Vostochnoiranskie yazyki [Languages of the World: Iranian Languages. III. Eastern Iranian Languages], edited by V. S. Rastorgueva, 225-242. Moscow: Indrik.

Fouse, G. 2000. The languages of the former Soviet Republics; their history and Development. University press of America, Oxford.

Griunberg, A.L., and I.M. Steblin-Kamenskii. 1989. Neskol'ko zamechanii po povodu otklika A.S. Davydova na stat'iu S.V. Cheshko [Some Remarks about A. S. Davydov's Comment on S. V. Cheshko's Paper]. Sovetskaia etnografiia 5: 35-38.

Guboglo, M.N., and F.G. Safin. 2000. Prinuditel'nyi lingvitsizm. Sotsiolingvisticheskie ocherki ob etnopoliticheskoi situatsii v SSSR v 1920-1930-e gody [Forced Linguicism: Sociolinguistic Essays on the Ethnopolitical Situation in the USSR in the 1920-1930s]. Moscow: TsIMO.

Hobsbawm, E.J. 1997. Are All Tongues Equal? Language, culture, and national identity. In Living as Equals. Edited by Paul Barker, 85-98. Oxford: Oxford university Press.

Isaev, M.I. 1990. Yazyki malochislennykh narodov SSSR: problemy funktsionirovaniia i sokhraneniia [Languages of the Minority Peoples of the USSR: Problems of Functioning and Preservation]. In Natsional'no-yazykovye problemy: SSSR $i$ zarubezhnye strany [NationalLanguage Problems: USSR and Foreign Countries], edited by K.V. Bakhnyan, 85-100. Moscow: INION AN USSR.

Karamshoev, D.K. 1977. Novoe v pamirskoi filologii [New in Pamir philology]. Voprosy iazykoznaniia 1: 126-133.

Karamshoev, D. 1991. Shugnansko-russkii slovar [Shugnani Russian Dictionary] Vol. 1. Edited by A.L. Griunberg. Moscow: Nauka.

Karamshoev, D. 1991. Shugnansko-russkii slovar [Shugnani Russian Dictionary]. Vol. 2. Edited by A.L. Griunberg. Moscow: Nauka.

Karamshoev, D. 1999. Shugnansko-russkii slovar [Shugnani Russian Dictionary]. Vol. 3. Edited by A.L. Griunberg. Moscow: Vostochnaia literatura.

Karamshoev, D. 2005. Russko-shugnanskii slovar [Russian Shugnani Dictionary] Vol. 4. Edited by I.M. Steblin-Kamenskiy. Dushanbe: Glavnaia nauchnaia redaktsiia Tadzhikskoi natsional'noi entsiklopedii.

Karamshoev, D. 2015. Slovar'pamirskikh lichnykh imen. [Dictionary of Pamiri Personal Names]. Vol. 5. Edited by Sh.P. Iusufbekov. Dushanbe: Donish.

Khudoerov, M.M. 2011. Problema pamirskoi avtonomii v Tadzhikistane na rubezhe 1980-1990kh godov [The Problem of Pamirian Autonomy in Tajikistan on the Eve of the 1980-1990s.]. Vestnik Cheliabinskogo gosudarstvennogo universiteta 46: 78-81.

Khudonazarov, D. 2008. Pamirskaia odisseia blagorodnogo finna. Eduard Kivikes i tadzhiki [Pamirian Odyssey of a Noble Finn. Eduard Kivikes and Tajiks]. Rodina 4: 76-80.

Kolesnik, N.G. 1990. Yazyki malochislennykh narodov SSSR: Sostoianie i perspektivy (Materialy "kruglogo stola", mart 1989 g.) [Languages of the Minority Peoples of the USSR: Status and Perspectives (Materials of the "Round-Table Discussion", March 1989]. In Natsional'noyazykovye problemy: SSSR i zarubezhnye strany [National-Language Problems: USSR and Foreign Countries], edited by K. V. Bakhnyan, 178-194. Moscow: INION AN SSSR. 
Kostomarov, V.G. 1991. Eshche raz o poniatii "rodnoi yazyk" [Once Again on the Notion of "Native Language"]. Russkii yazyk v USSR 1: 9-15.

Mandel'shtam, A.M. 1957. Materialy k istoriko-geograficheskomu obzoru Pamira i Pripamirskikh oblastei [Materials for the Historical and Geographical Overview of the Pamir and Pripamir Regions]. Stalinabad.

Martynova, M.Iu. 2020. Iazyk i shkol'noe obrazovanie. Rossiiskii opyt [Language and School Education. Russian Experience]. In Smert' iazyka - smert' naroda? Iazykovye situatsii i iazykovye prava v Rossii i sopredel'nykh gosudarstvakh [Death of Language - Death of a People? Language Situations and Language Rights in Russia and Neighboring States.] Edited by E.I. Filippova and S.S. Sokolovskii, 40-74. Moscow: Goriachaia liniia - Telekom.

Masov, R.M., ed. 2013. Bakhodur Iskandarov - uchenyi, pedagog i voin. Materialy nauchnoteoreticheskoi konferentsii, posviashchennoi 100-letiiu so dnia rozhdeniia akademika $B$. Iskandaroa (g. Dushanbe, 14 noiabria 2012 g.) [Bakhodur Iskandarov - the Scientist, Teacher and Warrior. Materials of the Scientific-Theoretical Conference Dedicated to the 100th Anniversary of the Birth of the Academician B. Iskandarov (Dushanbe, November 14, 2012)] Dushanbe: Donish.

Morgenstierne, G. 1928. Notes of Shughni. In Norsk tidsskrift for sprogvidenskap. Oslo. Bind 1. 32-84.

Morgenstierne, G. 1938. Indo-Iranian frontier languages. Vol. II. Iranian Pamirian Languages (Yidgha-Munji, Sanglechi-Ishkashmi, and Wakhi). Oslo.

Monogarova, L.F. 2001. Assimiliatsiia i konsolidatsiia pamirskikh narodov [Assimilation and Consolidation of Pamiri Peoples]. In Sredneaziatskii etnograficheskii sbornik. Vyp. IV [Central Asian Ethnographic Collection. Vol. IV], edited by V. I. Bushkov, 47-55. Moscow: Nauka.

Okhonniezov, V.D. 2012. Nodir Shambezoda va adabieti muosiri tojik [Nodir Shambezoda and Contemporary Tajik Literature]. Dushanbe: RTSU.

Okhonniezov, V.D. 2017. Paidoish va tashakkuli she'ri muallifi ba zabonhoi pomiri (dar misoli guruhi zabonhoi shughnoni-rushoni). Muharriri mas'ul professor N. Shakarmamadov. [The Origin and Development of Author's Poetry in the Pamirian Languages (the Example of the Shugnani and Rushani Languages.]. Edited by Professor N. Shakarmamadov. Dushanbe: Er-graf.

Pakhalina, T.N. 1969. Pamirskie iazyki. [Pamiri Languages]. Moscow: Nauka.

Rozhdestvenskii, Yu.V. 2002. Lektsii po obshchemu yazykoznaniiu [Lectures on General Linguistics]. Moscow: Akademkniga.

Shambezoda, Kh.D. 2007. Funktsionirovanie bespis'mennogo yazyka maloi narodnosti $v$ usloviiakh polietnicheskogo sotsiuma (na materiale shugnanskogo yazyka v tadzhiksko-russkom okruzhenii) [Functioning of the Non-Written Language of a Minor Nation in the Conditions of the Polyethnic Society (the Case of the Shugnani Language in Tajik-Russian Environment]. PhD diss., Russian-Tajik (Slavic) University, Dushanbe.

Shaw, R. 1876. On the Ghalchah Languages (Wakhi and Sarikoli). Journal of the Asiatic Society of Bengal XLV: 139-278. Calcutta.

Shugnon, Tahti 2014. Nazari akademik M. Ilolov va professor P. Jamshedov Shugnan. [Shugnan] Edited by M. Ilolov and P. Jamshedov. Dushanbe: Irfon.

Solntsev, V.M., and V.Yu. Mikhalchenko. 1990. Yazykovaia situatsiia v SSSR [Language Situation in the USSR]. In Natsional'no-yazykovye problemy: SSSR i zarubezhnye strany [NationalLanguage Problems: USSR and Foreign Countries], edited by K. V. Bakhnyan, 14-31. Moscow: INION AN USSR.

Tishkov, V.A. 2016. Iazyki natsii [Languages of the Nation]. Vestnik rossiiskoi akademii nauk 86 (4): 291-303.

Tishkov, V.A., and Kh.M. Akbaev. 2020. "Narod ne umiraet s iazykom" ili "Iazyk ne zhivet bez naroda". Dialog uchenykh o konflikte vokrug rodnogo iazyka ["The People Do not Die with the Language" or "The languages Does not live Without the People". Dialogue of Scientists About the Conflict Around Native Language]. In Smert' iazyka - smert' naroda? Iazykovye situatsii i iazykovye prava $v$ Rossii i sopredel'nykh gosudarstvakh [Death of Language - Death of the 
People? Language Situations and Language Rights in Russia and Neighboring States.], edited by E.I. Filippova and S.S. Sokolovskii, 19-39. Moscow: Goriachaia liniia - Telekom.

Xuan Zang. 2012. Zapiski o zapadnykh stranakh [epokhi] Velikoi Tan (Da Tan si iui tszi) [Notes on the Western countries [era] of the Great Tang (Da Tang si yu ji).]. Introduction. trans. and comment. N.V. Alexandrova. Moscow: Vostochnaia literature.

Tishkov, V.A. 2007. Rodnoi yazyk [Native Language]. In Etnokul'turnyi oblik Rossii: perepis'2002 goda [Ethnocultural Image of Russia: The Census of 2002], edited by V.V. Stepanov and V.A. Tishkov, 50-63. Moscow: Nauka.

Yusufbekov, Sh.P. 2011.Minoritarnye iazyki Pamira: Problemy i perspektivy razvitiia i izucheniia [Minority Languages of the Pamir: Problems and Prospects of Development and Study]. In Leksika, etimologiia, iazykovye kontakty. K iubileiu doktora filologicheskikh nauk, professora Dzhoi Iosifovny Edel'man [Vocabulary, Etymology, Language Contacts. On the Anniversary of the Doctor of Philological Sciences, Professor Joy Josephovna Edelman], 278-282. Moscow: Tezaurus.

Yusufbekov, Sh., and N. Ofaridaev. 2013. Vmesto Predisloviia [In Lieu of a Preface]. In Voprosy pamirovedeniia 7: 6-11.

Zaleman, K.G. 1895. Shugnanskii slovar' D.L. Ivanova [Shugnani Dictionary of D.L. Ivanov]. In Vostochnye zametki. Sbornik fakul'teta vostochnykh iazykov [Oriental Notes. Collection of the Faculty of Oriental Languages]. St. Petersburg.

Zamiatin, K., A. Pasanen, and I. Saarikivi. 2012. Kak i zachem sokhraniat'yazyki narodov Rossii? [How and Why to Preserve the Languages of the Peoples of Russia?]. Helsinki: Kirjapaino Oy.

Zarubin, I.I. 1924. Dva obraztsa pripamirskoi narodnoi poezii. [Two Samples of Pamirian Folk Poetry]. Otd. Ottisk iz Doklady Rossiiskoi Akademii nauk [Imprint of the Reports of the Russian Academy of Sciences], 177-180. Moscow.

Zarubin, I.I. 1925. Spisok narodnostei Turkestanskogo kraia [The List of Nations of the Turkestan Area]. Leningrad.

Zarubin, I.I. 1960. Shugnanskie teksty i slovar' [Shugnani Texts and Dictionary.] Moscow and Leningrad: Izdatel'stvo Akademii nauk USSR.

\section{Kalandarov, Tohir $S$.}

\section{From the history of the Pamirian languages: the future begins yesterday}

Pamirian Tajiks live in the high mountainous valleys of Pamir in the Republic of Tajikistan. They have preserved ancient East Iranian languages and their indigenous culture. Today more than 150 thousand people speak these languages in Gorno-Badakhshan Autonomous Region of the Republic of Tajikistan. The article analyzes the situation with the Pamirian languages in the Soviet time, as well as in the period of independence of the Republic of Tajikistan. The article consists of two parts, which describe the history and study the development of the Pamirian languages (taking the Shughni language as an example) during the Soviet and post-Soviet periods. It is concluded that much work is still need to be done in order preserve the Pamirian languages, although notable progress has been achieved. One of the priorities is to indicate the presence of these languages in the questionnaire of the upcoming population census of the Republic of Tajikistan in 2020.

Key words: Pamir, Tajikistan, census, native language, Pamirian languages, Shughni language 